\title{
Questões diversas sobre a história do espírito filosófico na França antes de 1750
}

\author{
Gustave Lanson \\ Traduzido por Leandro de Araújo Sardeiro ${ }^{*}$ \\ Revisão técnica de Edmilson A. de Azevêdo ${ }^{* *}$ \\ recebido: 01/2013 \\ aprovado: 03/2013
}

Eu queria escrever a história do movimento filosófico na França no século XVIII: parecia-me a cada dia mais que ela não foi ainda feita. Eu não sei se terei o tempo e a força de executar esse projeto que demanda uma infinidade de estudos preliminares. Sem mesmo tentar traçar um esquema cujos cursos que fiz na Sorbonne desde 1907 me forneceriam a rigor os dados ${ }^{1}$, mas de uma maneira ainda bem incompleta, eu pensei que pudesse ser de alguma utilidade apresentar aos leitores da Revue d'histoire littéraire alguns fatos e algumas observações que me pareceram merecer atenção. São menos resultados que começos de algumas enquetes que talvez eu não possa por algum tempo, ou jamais, estando sozinho, conduzir a seu termo. São menos respostas que dúvidas e sugestões: eu ficaria contente se alguns eruditos achassem aqui a ideia dos trabalhos a fazer, e se, seguindo as rotas cujos esboços me contento de marcar, eles quisessem mesmo acrescentar algumas contribuições precisas à história ainda tão mal desembaraçada do meio intelectual e moral que a envolveu e por uma grande parte determinou os grandes escritores da literatura francesa do século XVIII.

O palco principal, na nossa história, é ocupado, de 1713 a 1750 , pelos jansenistas e pelos ultramontanos que guerreiam entre si. As paixões políticas despertam seguindo as paixões

\footnotetext{
* Universidade Estadual do Piaui. Doutorando em Forme e Storia dei Saperi Filosofici nell'Europa Moderna. Università del Salento, US, Itália. Bolsista CAPES proc.BEX 5569/10-9.em@il: leosardeiro@yahoo.com.br

Universidade Federal da Paraíba-UFPB em@il: eazevedojp@gmail.com.
}

Problemata: R. Intern. Fil. Vol. 04. No. 03. (2013), p. 382-441 ISSN 2236-8612 DOI: http://dx.doi.org/10.7443/problemata.v4i3.16957 
religiosas e delas não se destacam. É para salvar o jansenismo que o Parlamento faz a guerra a Roma e aos bispos, que ele se erige em representante da nação e estabelece seu direito contra o direito do rei. Dificilmente lançamos em certos momentos um olhar para o lado da filosofia, que não parecia tão ameaçadora. Negações de privilégio ou de permissão tácita, exclusões sem escândalo de candidaturas acadêmicas, uma lettre de cachet ${ }^{2}$ contra Voltaire, uma decisão do Parlamento contra suas Lettres Philosophiques, algumas decisões do Parlamento e do Conselho contra outros livros, uma peça proibida ou retirada por ordem do teatro; eis o que se encontra e isso não faz efeito senão quando o retiramos do curso tumultuoso da vida, onde repercutem bem mais forte as querelas jansenistas e parlamentares.

Imaginamos geralmente o movimento filosófico como um fogo que por muito tempo chocou, lançando alguns lampejos intermitentes, até a altura de 1750 , e que muito subitamente refulgiu em violento incêndio. A moderação de Montesquieu, a indiferença relativa de Marivaux, Prevost, Piron, a predominância da atividade literária, interrompida somente por algumas extravagâncias filosóficas, na obra de Voltaire, contrastam com a impressão que dão na segunda metade do século o Dictionnaire Philosophique com os romances e todos os panfletos da boutique de Ferney, o Émile, a Encyclopédie, e todos os livros de Helvétius, de Holbach, Raynal e outros. Visto a voo de pássaro, e capturada nas linhas que traçam as grandes obras das quais nos lembramos, a literatura parece portar o testemunho de que o desenvolvimento da incredulidade radical e violenta se fez somente após 1750.

Tenho razões para crer que isso é um erro, ou ao menos uma interpretação inexata dos fatos. Sem que os livros abertamente hostis à religião e intrépidos negadores tenham faltado no início do século XVIII - o talento e o barulho que lhes faltou, e a existência deles foi breve, - o comércio de livros dá total razão à opinião vulgar. Mas é preciso observar que o comércio de livros informa sobre a evolução real do pensamento somente nos tempos e nos países onde a liberdade de imprimir é plena. Esse não era o caso da França do século XVIII, e ainda que a polícia do governo ou a da Igreja estivessem já um pouco relaxadas, seria prudente não admitir como uma coisa evidente, que a matéria impressa nesse tempo reflete exatamente o estado interior das consciências. A transformação do movimento filosófico que o comércio livreiro acusa após 1750 poderia bem 
estar relacionada mais a uma mudança de tática que a uma mudança das ideias; poderia ser que as vontades após 1750 se tivessem tornado mais determinadas, as paixões mais irascíveis, que as barreiras e os diques tivessem cedido, e que assim se tivesse desde então publicado sem medo o que antes se dizia a portas fechadas e sussurrando.

Afora a crítica dos incrédulos após 1750 , não havia nada de novo. Mas houve menos novidade que a série de obras impressas daria a crer a primeira vista. Encontra-se desde o fim do século XVII e nos primeiros anos do século XVIII, negações altivas, radicais, veementes, injuriosas, negações blindadas de erudição e aprofundadas de ciência ou de metafísica, que golpeiam todo o aparelho de dogma, de história e de filosofia sobre o qual o cristianismo repousa. Mas essas negações, salvo exceção, permaneceram manuscritas, ou sempre, ou por muito tempo. Diversas das obras mais audaciosas ou mais violentas que foram impressas após 1750, que nos permitem estudar a grande batalha de 1760-1770, datam em realidade do começo ou pelo menos da primeira parte do século XVIII.

$\mathrm{Eu}$ o suspeitei folheando o catálogo dos manuscritos das bibliotecas, examinando um certo número de manuscritos da Biblioteca Nacional, do Arsenal, e da Mazarine. Seria desejável que um estudo exato dos numerosos manuscritos filosóficos do século XVIII que as bibliotecas provinciais possuem completasse as informações ainda bastante insuficientes que uma rápida enquete nas bibliotecas de Paris me forneceu.

Também seria bom que se notasse por cruzamento, nos escritos de controvérsia e de apologética, as menções que se fazem de manuscritos ímpios, e as datas dessas menções.

Seria bom que se fizesse uma lista das cópias conservadas, tentando estabelecer a época de sua fabricação, ou da fabricação do original do qual elas derivam, e que se nos desse, por uma pesquisa tão completa quanto possível, o meio de conjeturar, segundo o número de cópias, a difusão possível das ideias.

Porque esses manuscritos circulavam. As suas cópias se multiplicavam. Pagava-se muito caro por elas às vezes. Por volta de 1745, pagava-se pelos Pensées do cura Meslier oito ou dez luíses de ouro ${ }^{3}$. Havia ateliês e comerciantes de manuscritos perigosos, escritos jansenistas, libelos difamatórios, obras ímpias. A polícia os perseguia ${ }^{4}$. Os Arquivos da Bastilha nos fazem entrever esse comércio. 
No início de 1725, prendeu-se dois gazeteiros, Lecoulteux e Bonnet, e os sete vendedores de Lecoulteux. Havia tantos papéis na casa de Lecoulteux que se deveu desistir de transportá-los; eles foram somente colocados sob sigilos. Dentre eles se encontravam alguns manuscritos de Boulainvilliers: ignoro se eram suas obras históricas ou suas obras filosóficas. A segunda hipótese é mais provável, segundo a descoberta que se fez na casa de Bonnet. Apreendeu-se ali "um manuscrito contendo 300 rolos in-fol., tendo por título La vie et l'Esprit de Spinosa". Bonnet declarou trabalhar por conta de Lecoulteux e ter feito cinco a seis cópias do manuscrito. Lecoulteux reconheceu ter encomendado três cópias deste que vendera ao conde de Toulouse, ao bispo de Blois e ao senhor de Caraman. O tenente de polícia, Doutreval, enviou o manuscrito de la Vie et $l^{\prime}$ Esprit de Spinoza ao Duque: esse foi um leitor a mais ${ }^{6}$.

Quatro anos depois, nova descoberta. Uma denúncia é enviada à polícia em 9 de agosto de 1729 .

\footnotetext{
... senhor Mathieu ou Morléon que mora em um café na esquina da rua Saint-Dominique, do lado da Charité, debita e vende cópias de diversas obras plenas de impiedade e de máximas contrárias à existência de Deus, à divindade e à moral de J.C. Muitas pessoas, abades e outras, compram-lhes bem caro cópias de suas obras...

Será encontrado entre essas sortes de compradores um abade que foi tomar posse de uma abadia ao lado de Verdun?
}

Haymier, inspetor de polícia, transporta-se então à casa de Mathieu ou Morléon a quem ele compra manuscritos tratando "da história do primeiro homem, da história do Egito, dos patriarcas desde a vocação de Abraão até o êxodo dos Israelitas", que ele envia ao tenente de polícia, senhor Hérault ${ }^{8}$.

Há outros desse, diz Haymier, que tratam da vida de J. C., de sua origem e dos erros que a gente introduziu depois de sua morte. Não me foi possível tê-los, não querendo dá-lo por menos de 20 pistolas... Ele me disse também que não havia um só oficial no Parlamento que não tivesse desses manuscritos em sua casa ${ }^{9}$.

Morléon era um antigo subtenente do regimento de Charolais. Ele admitiu ter vendido esses manuscritos; ele não tinha outra indústria para subsistir. Levaram-no à Bastilha, onde ele permaneceu de 20 de agosto a 19 de setembro de 1729; Ele 
foi solto sob promessa de não recomeçar.

A polícia se ocupa em 1741 de um certo La Barrière, escriturário das damas de Montmartre, que morava no alto do Porcherons ${ }^{10}$. Ele trabalhava como fornecedor dos vendedores ambulantes $^{11}$ de livros e de manuscritos perigosos. Ele é assinalado como tendo dado ao pequeno Guillaume alguns exemplares da Liberté de penser: eram sem dúvida cópias manuscritas; nem Barbier nem Quérard assinalam essa obra, que não foi talvez impressa. E acrescenta-se que "La Barrière sempre fez profissão de escritor para esses tipos de obras, e vendeu em seu tempo a obra do cura de Trépigny (ou seja os Pensées de Jean Meslier, cura de Etrépigny) ${ }^{12,}$.

Em 1747, prende-se um preceptor e um mestre de bairro do colégio de la Marche, Letort e Garnier. Eles são denunciados por um operário impressor, como tendo dado à impressão três obras das quais as duas primeiras são assim designadas:

$1^{\mathrm{o}}$ Histoire suivie de l'Inquisition exercée à Roma, en Espagne et en Portugal, avec des réflexions critiques d'un auteur sceptique dans le système de raison sur la religion.

$2^{\circ}$ Système de raison sur la religion, où l'auteur sceptique les frappe toutes.

Letort e Garnier declararam não conhecer "os autores dos manuscritos, que são peças antigas", e ignorar "se foram feitas cópias". Garnier pareceu ser somente um confidente: prendeu-se Letort na Bastilha de 8 de maio a 10 de dezembro de $1747^{13}$.

Esses fatos mostram bastante que o pensamento irreligioso tinha uma certa difusão; ele permanecia entretanto evidentemente como privilégio de uma aristocracia rica. A prudência, por outro lado, impunha limites a sua circulação. Mostrava-se esses escritos somente às pessoas certas. Às vezes, para maior garantia, a obra ímpia se dissimulava nas bibliotecas ou no cesto do vendedor ambulante sob um título edificante; e se um curioso visse no dorso de um in-fólio as palavras: Existence de la foi chrétienne, ou se, abrindo-o, ele lesse na primeira página o título: Motifs pressants pour exciter la foi des chrétiens et pour leur en faire fréquemment produire des actes ${ }^{14}$, quase não podia imaginar que ao tomar conhecimento disso, tivesse então encontrado uma das mais vigorosas críticas da religião que tenham sido feitas nesse século ${ }^{15}$.

Eis aqui algumas dessas obras: começo pelos escritos de 
dois curas ${ }^{16}$.

\section{PIERRE CUPPÉE.}

"LE CIEL OUVERT À TOUS LES HOMMES, TRAITÉ
THÉOLOGIQUE (por Pierre Cuppée), 1768, in- $8^{\circ}$."
O escrito que Barbier no seu Dicionário de obras anônimas ( $3^{\mathrm{a}}$ edição) assim nos apresenta é anterior de mais de meio século à publicação que se fez dele. Uma segunda edição mais correta e mais completa foi dada em 1783.

O título completo da obra é: Le ciel ouvert à tous les hommes, ou traité théologique dans lequel, sans rien déranger des preuves de la religion, on prouve solidement, par l'Écriture sainte et la raison, que tous les hommes sont sauvés ${ }^{17}$.

A intenção de Cuppé é clara. Ele chocava não somente os jansenistas, mas a ortodoxia mais ampla, aquela de Massillon, aquela mesma dos jesuítas. Ele conduzia a religião ao deísmo, ao racionalismo. Ele convidava o leitor a "consultar mais sua razão que as falsas prevenções de que ele se encheu nas escolas ${ }^{18 \%}$. Para tornar odiosa a tese do pequeno número de eleitos, ele esboçava uma estatística comparável à famosa nota dos danados que fez em uma edição da Henriade um grande escândalo. Era, senão violento, ao menos insolente para um padre.

Em notas inscritas sobre duas cópias da Biblioteca Nacional $^{19}$, Gayet de Sansale, que foi bibliotecário da Sorbonne ao fim do século XVIII, nos diz que se procurava muito essa obra ímpia e perigosa antes que ela tivesse sido impressa em 1768. A Sorbonne possuía três exemplares dela em $1788^{20}$, e recebeu um outro em 1790 do abade Dous, cônego da catedral de Beauvais ${ }^{21}$.

Há dela atualmente seis cópias na Biblioteca Nacional ${ }^{22}$, duas na $\operatorname{Arsenal}^{23}$ e duas na Mazarine ${ }^{24}$. Um livreiro de Niort, em 1881 , oferecia uma datada de $1732^{25}$. Eu vi também que a biblioteca de Châlons-sur-Marne possui duas cópias dela ${ }^{26}$, das quais uma é datada de 8 de agosto de 1756 e foi feita, diz-se, a partir do manuscrito autógrafo. A obra se encontra sem nenhuma dúvida em outras bibliotecas provinciais, e pode-se crer que ela se difundiu bastante no clero: ela devia interessar 
menos aos laicos, para os quais as tendências racionalistas exigiam desde muito tempo conclusões muito mais fortes contra a religião.

Pierre Cuppé era um cônego regular de Santo Agostinho, que foi cura de Bois, na diocese de Saintes. Um de nossos manuscritos contém uma cópia da retratação que se lhe fez fazer em Saintes, no Palácio episcopal, em 10 de setembro de 1716.

Cuppé compareceu diante do abade de Vaux e do abade Savalette, vicários gerais, do teologal Nozerines, do senhor Michel, superior do seminário, do irmão Celso e do irmão Siméon, um provincial e outro custódio dos Récollets ${ }^{27}$, enfim do padre Tartas, reitor do colégio dos Jesuítas. Os vigários gerais tendo assegurado que seu "tratado, longe de levar consolo aos homens, seria capaz de causar problema na religião, por causa dos erros que ele contém e das consequências que se lhe poderia tirar contra a moral cristã", o cura de Bois declarou "condenar, detestar e anatematizar de todo seu coração" seu desencontrado escrito, e prometeu "obedecer cegamente" ao Monsenhor de Beaumont, quando ele viesse na diocese ${ }^{28}$, "para queimá-lo, retratá-lo ou fazer tudo o que lhe agradasse".

Ele não manteve sua promessa, e deveu-se punir severamente contra ele? Um outro manuscrito contém a nota seguinte $^{29}$ :

Esse cura, aos vinte e quatro anos de idade, tendo tido a imprudência de fazer imprimir seu livro, o que bem prova que ele estava de boa fé, foi colocado em prisão junto aos Récollets de Xaintes, onde fez-se-lhe fazer uma retratação na forma que foi impressa e que se vende publicamente. Esta chegou no mês de fevereiro de 1744.

Eis todo o esclarecimento que pude encontrar sobre essa questão. Em 1744, Monsenhor de Champflour, bispo de Mirepoix, recebeu uma carta de Pierre Cuppé, que dizia, que por ter sabido que seu escrito circulava nas dioceses de Toulouse e de Mirepoix e arriscava de avariar as almas, enviava-lhe cópia de sua retratação. Ele assinalava que "fora até preso naquela ocasião". O bispo não suspeitava nada, não recebera nem queixa nem recomendação, e não sabia o que essa carta queria dizer. Ele escreveu então em 4 de março ao bispo de Saintes para buscar esclarecimentos. Não se tem a resposta do Monsenhor de Beaumont.

Assim falou-se novamente do Ciel ouvert em 1744; 
Houve inquietação em Saintes, colocou-se Pierre Cuppé em um convento; ele teve que dar nova publicidade à sua retratação. Mas ela era bem anterior, como se viu. E, por outro lado, não há traço de edição em 1744: não se trata senão de cópias que correm. O autor da nota do ms. 1176 da Mazarine soube das coisas somente por alto.

É verdade que Cuppé era então octogenário: ele tinha oitenta e quatro anos. Ele devia estar muito enfraquecido, e essa chicana precipitou talvez seu fim. Pois ele morreu seis ou sete semanas depois, em 27 de abril de 1744, munido dos sacramentos da Igreja ${ }^{30}$.

\section{II}

\section{Jean Meslier}

Os filósofos não se interessaram por esse bom homem: eu não creio que um só, nem mesmo Voltaire, tenha pronunciado o seu nome: ele era muito cristão para eles, e eles se preocupavam menos em ser salvos do que em não ter Salvador. Por isso Jean Meslier encontrou mais acolhida junto a eles que Pierre Cuppé.

TESTAMENT DE JEAN MESLIER, NOUVELLE ÉDITION, s.l. n.d. (Genève, 1762), in- $8^{\circ}$ de 64 páginas ${ }^{31}$.

Sabe-se que Voltaire é o autor dessa publicação. Sabe-se também que o extrato fala somente de uma parte do enorme manuscrito do cura, sobre aquilo que podia agradar aos deístas e atacava somente a religião cristã. A obra completa foi publicada em 1864 em Amsterdã, por Rudolf Charles (R. C. d'Ablaing von Giessenburg $^{32}$ ).

Meslier, que era desde 1692 cura de Etrépigny e de Balaives, morreu sem dúvida em 1729. O último ato assinado por ele sobre o registro paroquial é de 7 de maio, e o primeiro de seu sucessor é de 27 de agosto.

Voltaire ouviu falar desse cura pela primeira vez em 1735; foi uma carta de Théiriot que lhe informou que o estranho testamento começava a fazer barulho em Paris. Os três exemplares primitivos se multiplicaram rapidamente. $\mathrm{O}$ conde de Caylus, que tinha um desses, deixou que fossem feitas cópias $^{33}$. Por volta de 1740 ou 1745, como vimos, a obra se dava 
por 8 ou dez luíses de ouro ${ }^{34}$. Em 1762, Voltaire pretende que "há mais de cem exemplares dessa obra em Paris" 35 ". Ela passou até para o exterior. É pouco provável que a cópia encontrada na Holanda por R. C. d'Ablaing de Giessenburg, e sobre a qual ele faz sua edição ${ }^{36}$, tenha sido levada para lá no século XIX.

A Biblioteca Nacional possui três exemplares de pequeno formato quadrado, de uma escrita miúda, que devem ser as mais antigas cópias que se tenham feito ${ }^{37}$. As duas cópias da Arsenal $^{38}$ são muito belas. Há uma outra em Fécamp ${ }^{39}$, e outras sem dúvida nas bibliotecas cujos catálogos não pude ainda interrogar.

Fez-se também um extrato ou extratos que circularam. Há um manuscrito na Arsenal ${ }^{40}$, dois em Rouen, dos quais um é datado de 15 de março de $1742^{41}$, um outro em Fécamp ${ }^{42}$, que se dá como escrito pela mão de Diderot. Ignoro se esses extratos estão conformes entre si. A data do manuscrito 1573 de Rouen é aquela que Voltaire deu ao extrato na sua edição: é então provável que esse manuscrito contenha, com mais ou menos variantes, o texto de Voltaire.

Eu examinei somente o ms. 2558 da Arsenal. Lê-se sobre a primeira folha a nota seguinte:

Ordeno que depois de mim queime-se o manuscrito. Embora muito mal feito, ele foi copiado como um manuscrito raro e precioso, feito para ser visto somente por pessoas firmes nos seus princípios. Em $1^{\circ}$ de janeiro de 1763. DUCHESNE.

E, ao fim do extrato, o possuidor nota que ele foi impresso no Évangile de la raison $(1765)^{43}$. Está somente metade exato. A publicação de Voltaire não trazia nem o Aviso ao leitor do manuscrito, nem a apresentação, que apareceu somente na segunda edição, e mesmo assim bastante reduzida. Seria preciso ver se o Recueil nécessaire avec l'Évangile de la raison $^{44}$, 1768 , que cita Bengesco ${ }^{45}$, como dando o Aviso ao leitor e uma apresentação mais longa, seguida do texto do manuscrito da Arsenal.

Em relação ao extrato mesmo, o manuscrito dá três capítulos que correspondem aos quatro primeiros de Voltaire. Há numerosas diferenças de redação: sempre onde Voltaire, de acordo com o Testament completo, escreve Cristícolas ${ }^{46}$, o manuscrito dá Cristão. Todo um desenvolvimento sobre a conformidade das cerimônias pagãs e cristãs que vem, diz o manuscrito, de uma dissertação de Angelo December Milanois, 
conservada em um manuscrito de Baluze na biblioteca do Rei, é ausente na edição de Voltaire. Por outro lado os capítulos V e VI de Voltaire estão ausentes no manuscrito da Arsenal.

Sempre se pensou que o Abrégé de la vie de Jean Meslier, que precede o extrato impresso por Voltaire, fosse dele. $\mathrm{O}$ manuscrito da Arsenal fornece razões para dúvida. Primeiro, ele parece muito ser anterior à publicação de Voltaire. Depois, ele fornece um outro texto. Enfim, entre as variantes do Abregé de la Vie, há duas que dificilmente podem ser imputadas a Voltaire.

Ele fazia frequentemente a caridade, era sóbrio, e muito contido, diz o manuscrito. Esse "contido" trai uma pluma eclesiástica. Voltaire imprime:

... fazendo frequentemente a caridade, por outro lado muito sóbrio tanto sobre sua boca que sobre as mulheres ${ }^{47}$.

O manuscrito diz:

Tendo entretanto feito seus estudos, ele chegou ao sacerdócio sem vocação.

Essas duas palavras, que parecem uma condenação, desaparecem do texto de Voltaire:

... ele entretanto fez seus estudos e chegou ao sacerdócio.

Voltaire recortou uma anedota interessante do Abregé manuscrito. Ei-la aqui (ela não é porém inédita) ${ }^{48}$ :

Em uma viagem que ele fez a Paris por volta do tempo em que apareceu pela primeira vez o tratado do abade Houtteville sobre a religião, o Padre Buffier, amigo do cura, propôs-lhe de ler essa obra para que lhe dissesse o seu sentimento a esse respeito. Meslier o consentiu sob a condição de que o lessem juntos. Alguns dias após, enquanto jantava com os Jesuítas na companhia de um jovem homem do grupo destes que são sem religião, bem mais por vaidade que por princípios, a conversa correu sobre o tratado em questão; o jovem homem abandonou-se aos tratos malignos pelos quais se pretende pela razão fulminar os motivos de credibilidade. Meslier replicou com um grande sangue frio que não se tratava de ter espírito para se escarnecer da religião, mas que era preciso muito para defendê-la. 
A palavra tem um duplo sentido. Ela significa, tendo o ar de ferir o libertino, que a religião é mais fácil de combater do que de demonstrar e que os bons argumentos são raros. Entretanto Voltaire suprimiu a anedota onde Meslier aparecia em uma atitude equívoca. Parece então mesmo que ele não escreveu o Abregé e que ele se limitou a fazer-lhe a toalete ${ }^{49}$. Poderíamos nos perguntar se não se passa o mesmo com todo o Extrait: seria preciso comparar seu texto àquele das diversas cópias manuscritas que estão nas bibliotecas.

Retorno ao Testament completo.

Naigeon $^{50}$ diz que as últimas linhas dessa obra eram:

Eu queria, e esse será o último e como o mais ardente dos meus desejos, eu queria que o último dos reis fosse estrangulado com as tripas do último dos padres ${ }^{51}$.

É na apresentação de Meslier que se encontra a ideia dessa frase, da qual Diderot tirou dois versos tão célebres quanto sinistros.

Eu me lembro... lê-se ali, do desejo de um homem que sem estudo tinha muito senso. Eu desejaria, dizia ele, que todos os tiranos fossem enforcados com as tripas de padres ${ }^{52}$.

Voltaire arregimentara Meslier a serviço do deísmo, contra o dogma católico: ele o apequenara e o atenuara. Meslier queria fazê-lo a todas as religiões, como à cristã, à religião natural, à metafísica espiritualista, enfim a toda a ordem social, reis, grandes, juízes, ricos. Ele era ateu, comunista e libertário. Ele não media as palavras: ele as proferia nominalmente aos reis da França. Ele era verdadeiramente feroz, e seu grosso manuscrito é o requisitório mais copioso e o mais raivoso que se possa imaginar contra o trono e o altar. É possível mesmo que ele tenha se referido aos padres somente porque eram o apoio dos reis. Seu racionalismo não se irritava tanto contra o erro e o prejuízo senão porque perpetuavam a injustiça social.

O Abrégé de la vie se engana dizendo que Meslier empregou seus sentimentos somente na leitura da Bíblia e dos Padres. Basta folhear o Testament para perceber que Meslier está pleno de Montaigne, que utiliza Pascal, La Bruyère, Bayle, Gabriel Naudé, o Télémaque, e, bastante abundantemente, Comines e o Espião turco, que ele estudou a Recherche de la 
vérité e todo o sistema de Malebranche, assim como o Traité de l'Existence de Dieu de Fénelon, que anotou muito vivamente ${ }^{53}$. $\mathrm{O}$ Testament contém longas e vivas refutações das demonstrações que Descartes e os cartesianos, Malebranche e Fénelon, deram da existência e da perfeição de Deus, da criação, da espiritualidade e da imortalidade da alma, etc.

Meslier não pronuncia, eu creio, o nome de Espinosa: mas toda a parte metafísica do Testament é um curso de espinosismo, tal qual se podia fazê-lo entre 1700 e 1730 . O ser é incriado; as verdades são eternas; as coisas são possíveis ou impossíveis nelas mesmas, e não por uma vontade exterior; a substância é única; o mal é necessário como tudo é necessário, etc. Parece-me impossível que, direta ou indiretamente, Meslier não tenha recebido sua instrução filosófica de Espinosa. Vê-se ai o efeito que o autor da Éthique tinha sobre as pessoas do século XVIII. No Aviso ao leitor do ms. 2558 da Arsenal, Meslier é dado como um novo Messias cujos precursores foram Montaigne, Espinosa e Bayle, e ele é colocado acima de Moisés, Jesus e Maomé, ou seja dos Três impostores ${ }^{54}$. Não era convidar aqueles que liam o tratado francês dos Trois imposteurs, ou melhor o Esprit de Spinosa, a ver na obra de Meslier a continuação, o acabamento da doutrina desse pequeno livro, e por consequência uma expressão do espinosismo?

Haveria lugar para fazer também um estudo atento do Testament para estabelecer sua relação com certas outras obras ímpias que circularam em manuscrito, e notadamente com o Militaire philosophe e com as Doutes sur la religion sobre as quais falarei mais adiante. Seria preciso determinar se a relação consiste em uma influência de um sobre o outro (e de qual?), ou em um uso comum de argumentos bebidos na mesma fonte.

Voltaire não era indulgente com o estilo desse cura do campo, que achava muito repulsivo ${ }^{55}$. Não se pode dizer que Voltaire estava completamente errado. Jean Meslier escreve pesadamente, prolixamente, grosseiramente. Mas há energia na sua amargura impetuosa. Parece-me que seria preciso classificálo em um grupo de escritores que representem um estado interessante da língua, do estilo e do gosto. Enquanto o vocabulário e a frase, pela ação da boa sociedade, da Academia e dos gramáticos, se purificavam na segunda parte do século XVII, se refinavam, se aliviavam, de modo que se passava da maneira de escrever de Pascal e de Corneille àquela de BussyRabutin, de Fontenelle, d'Hamilton, e enfim de Voltaire, havia 
na França, na burguesia e na nobreza, sobretudo em província, pessoas que esse trabalho e essa mudança não atingiam. Encontra-se no século XVIII, em toda sorte de obras, e notadamente nas cartas e nas memórias, estilos pelos quais se diria que nem Vaugelas, nem Bouhours, nem a bela literatura do grande reino existiram; eles parecem simplesmente prolongar a frase de Descartes, de Chapelain, do cardinal de Richelieu, de Scarron, religar-se para além dessa idade ao francês ao qual Rabelais ou d'Aubigné oferecem os modelos artísticos. Assim se explicam as incorreções, as asperezas, os emaranhamentos, os pesos, as rudezas do marquês d'Argenson e do marquês de Mirabeau, também o verdor destes, seu pitoresco e originalidade. $\mathrm{Eu}$ lhes acrescentaria o senhor de Boisguillebert, o marechal de Vauban e o conde de Boulainvilliers, que, com menos sabor, têm o mesmo fundo da língua e o mesmo tipo de discurso. $\mathrm{O}$ mestre do grupo, o artista de gênio, incompreensível quando o isolamos, e que o consideramos somente entre Marivaux e Voltaire, é Saint-Simon.

O pobre cura Meslier, com seu falar duro, denso e solavancado, arrastando em cem repetições e se engajando em cem desvios, mas que acaba às vezes por lançar, eu ia dizer por cuspir, a expressão nervosa e forte, é da mesma família ${ }^{56}$.

Escutemos somente as últimas palavras de sua primeira carta aos Curas: ele os dispensa de "dizer-lhe um devoto Requiescat ${ }^{57}$ "; ele não terá necessidade disto: quando eles lerem sua carta, ele estará morto.

Eu não saberia mais a esse ponto o que é repouso nem paz, nem o que é bem nem mal. É preciso viver para sabê-lo. Os mortos não sabem mais nada disto.

E o Testament cai também sobre essa palavra: “nada”. É a ela que leva o interminável desfile de suas provas contra todas as religiões e contra as metafísicas espiritualistas, na página 982 do ms. in-4 $4^{\circ}$ da Arsenal $^{58}$ : "E logo eu não serei nada". Eis por outro lado a página:

Eu jamais cometi algum crime nem alguma miserável nem má ação. Eu desafiaria bem presentemente todos os homens a poder me fazer com justiça ou argumento alguma má admoestação, de sorte que se eu sou injuriosamente e indignamente tratado, perseguido ou caluniado depois de minha morte, isso não será por outro crime que por aquele de ter dito ingenuamente a verdade, como a disse até aqui, a fim 
de vos dar, e a todos os semelhantes, possibilidade de poder (se quiserdes bem vos ouvir) tirar-vos e entregar-vos de todos esses detestáveis erros, superstições e abusos nos quais estais tão miseravelmente mergulhados. É a força da verdade que me faz dizê-la, e é somente a raiva da injustiça, da impostura, da tirania e de toda outra iniquidade que me faz falar assim...

Após isso, que se pense a seu respeito, julgue-a, que se diga e faça tudo o que se quiser no mundo sobre ela, eu quase não me preocupo; que os homens se acomodem e que eles se governem como eles querem, que eles sejam sábios ou que eles sejam loucos, que eles sejam bons ou que eles sejam cruéis, que eles digam ou que eles façam mesmo de mim tudo o que eles queiram depois da minha morte, isso me atormenta muito pouco. Eu já quase não tomo parte no que se faz no mundo; os mortos, com os quais estou perto de ir, não se preocupam mais com nada, eles não se misturam [mais] com nada e não se atormentam mais com nada. Acabarei então aqui pelo nada: também não sou eu mais quase que um nada, e logo não serei $\operatorname{nada}^{59}$.

E eis aqui na obra desse cura do vilarejo, antes de 1729, uma eloquência de clube de 93:

Onde estão esses generosos assassinos de tiranos que vimos nos séculos passados? Onde estão os Brutus e os Cassius? Onde estão os generosos assassinos de um Calígula e tantos outros? Onde estão os Publicola ${ }^{60}$ ? Onde estão esses generosos defensores da liberdade pública, que caçavam os reis e os tiranos de sua pátria e que davam licença a qualquer particular para matá-los?... Mas, na sua ausência, onde estão os Jacques Clément e os Ravaillac de nossa França? Que não vivem mais, esses generosos assassinos de tiranos! Que não vivem mais em nossos dias para abater ou para apunhalar todos esses detestáveis monstros e inimigos do gênero humano e para livrar por esse meio os povos de sua tirania...!

Mas não, eles não vivem mais, esses grandes homens! Não se vê mais dessas almas nobres e generosas que se expunham à morte para a saúde de sua pátria, e que preferiam a glória de morrer generosamente do que ter a vergonha e o desprazer de viver indignamente ${ }^{61}$.

E ele agredia, com o mesmo ardor enraivecido, todos os serviçais dos tiranos, juízes, magistrados, intendentes, governadores, comandantes das armas, oficiais e soldados,

... sem falar ainda de uma infinidade de outras canalhas ou comissários de escritórios, de controladores, de coletores de impostos, de arqueiros, de guardas, de sargentos, de escriturários e de meirinhos, que todos, como lobos famintos, 
buscam somente devorar a presa, e gostam somente de pilhar e tiranizar os pobres povos sob o nome e a autoridade do Rei executando rigorosamente sobre eles as mais injustas ordens, tanto por execuções, tanto por confiscamento de seus bens, e o que é ainda mais odioso, frequentemente por aprisionamento de suas pessoas e por todas as sortes de violências e de maus tratos, e enfim pelo chicote, pela pena das galeras, e às vezes até por uma morte vergonhosa que eles lhes fazem sofrer ${ }^{62}$.

Ele exortava o povo ao extermínio de todos os tiranos:

Quais são essas orgulhosas nações sobre as quais é dito nos mesmo livros ${ }^{63}$ que Deus fará secar as raízes? Não são outros que essas cruéis e orgulhosas nobrezas que estão entre vós, que vos pisam e que vos oprimem. Não são outras senão todos esses oficiais de vossos príncipes e de vossos reis, todos esses orgulhosos intendentes e governadores de cidades ou de províncias, todos esses orgulhosos recebedores de talhas e impostos, todos esses orgulhosos coletores de impostos e empregados dos escritórios, e enfim todos esses soberbos prelados e eclesiásticos, bispos, abades, mínimos, grandes beneficiários e todos esses outros eclesiásticos, assim como todos esses senhores, senhoras e senhoritas, que não fazem nada senão se divertir no mundo, e se dar toda sorte de bom tempo, enquanto é preciso, vós outros pobres povos, que vós vos ocupais dia e noite do trabalho, e que vós levais todo o peso do jugo e que vós sedes encarregados de todo o fardo do estado. Estão ali, meus caros amigos, estão ali as verdadeiras nações soberbas cujas raízes deveríeis bem fazer secar ${ }^{64} \ldots$

Compreende-se que Voltaire não tenha achado bom "extrair" do Testament essa Carmagnole ${ }^{65}$ antecipada. Mas o pobre cura foi também frustrado da revanche que ele esperava. Ele se calara toda sua vida: ele fizera seu dever de padre exteriormente, saboreando a esperança de que um dia seu pensamento secreto fosse até o povo, o desencantasse das superstições e lhe desse a coragem de lançar abaixo todos os tiranos. E seus Pensées, tão cuidadosamente consignado em três exemplares, não descia até o povo, não servia senão como divertimento de alguns ricos ou nobres letrados que podiam pagar muitíssimo pela sua cópia. E um dos melhores entre esses que queriam mal aos padres e aos reis, deixava filtrar somente alguns raios de luz, as quais podiam inundar os espíritos. Voltaire abafava a voz revolucionária do bom homem Meslier, e travestia esse selvagem ateu em pregador anódino de um deísmo burguês que não podia impedir a boa companhia de dormir e de 
jantar.

Se a Meslier e a Cuppé juntarmos somente o padre Buffier e o padre Le Courayer, teremos uma ideia do modo como o espírito filosófico tocou o clero nos primeiros anos do século XVIII. O movimento vai do padre Buffier, de ortodoxia intacta, até o ateu Meslier: entre essa extrema direita e essa extrema esquerda, Cuppé e le Courayer, aplicando a razão ao dogma e à história da Igreja, constroem novidades temerárias ${ }^{66}$.

\section{III \\ BOULAINVILLIERS.}

Venhamos agora aos laicos. Não me deterei muito tempo com o conde de Boulainvilliers, já bastante conhecido, mas que olhamos mais como uma exceção singular: ele é pelo menos chefe de coro, e representativo de uma bastante numerosa categoria de espíritos ${ }^{67}$.

Ele publicou durante sua vida somente uma carta $D e$ Hipócrates a Damagète (Colônia, 1700). Em 1730 foi impressa sua Vie de Mahomet (1730): não esquecer que Maomé é o terceiro dos grandes Impostores, mas o mais simpático, como ajudando a destruir os dois outros.

Em 1731, Lenglet-Dufresnoy publicou a Réfutation des erreurs de Benoît de Spinoza, par M. De Fénelon, archevêque de Cambrai, le P. Lamy Bénédictin, et Boulainvilliers, avec la Vie de Spinoza écrite par Colerus, augmentée de beaucoup de particularités tirées d'une vie manuscrite de ce philosophe faite par un de ses amis (in-12, Bruxelas). Título político e astucioso: Fénelon e Lamy com suas refutações encurtadas serviam somente de cobertura e de passaporte à exposição de Boulainvilliers, que não se propunha senão a colocar o sistema da Ética de Espinosa em todo seu esplendor, deixando a outros a tarefa de combatê-10 ${ }^{68}$.

Enfim em 1767 apareceu, seguindo as Doutes sur la Religion, a Analyse du Traité théologique-politique de Espinosa.

$\mathrm{O}$ primeiro dos dois escritos espinosistas de Boulainvilliers correu em manuscrito, antes e após a impressão.

A pretensa Réfutation se intitula mais frequentemente nas cópias Essai de métaphysique dans les principes de Spinosa, ou de um título análogo e também franco: há duas cópias dele na Biblioteca Nacional ${ }^{69}$, duas na Arsenal $^{70}$, duas na Mazarine ${ }^{71}$. 
Ela é acompanhada em geral da mesma Vie que no volume de 1731: mas a redação da Vie é às vezes bastante resumida ${ }^{72}$, sobretudo a segunda metade.

O título do ms. 2236 da Arsenal diz que ele foi "copiado do original do autor ao mês de agosto de 1712". A obra, segundo nos diz o Prefácio, fora começada antes de 1696, e foi terminada posteriormente a 1704, após a aparição das obras póstumas de Espinosa.

A análise do Traité théologique-politique é, segundo o mesmo prefácio, anterior. Encontrei somente um único manuscrito dela em Paris ${ }^{73}$.

Um manuscrito da biblioteca de Montivilliers contém um Promenade de Cléobule que uma nota escrita no interior da capa atribui a Boulainvilliers. Nem Barbier ${ }^{74}$, nem Quérard conhecem esse opúsculo, que eu não vi ${ }^{75}$.

Eles ignoraram também as Recherches curieuses de philosophie do qual a Biblioteca Nacional possui um manuscrito, e que o catálogo dá, não sei sobre qual fundamento, como atribuído a Boulainvilliers ${ }^{76}$.

Eis aqui o título exato da obra:

Recherches curieuses de philosophie ou Dissertation sur les principes des choses naturelles, dans laquelle, par le secours d'une méthode nouvelle, on traite de la génération des hommes, des animaux, des arbres, des plantes, de la formation du monde et de sa durée, des causes des vents, du tonnerre, de la foudre, de l'esprit, du raisonnement.

Por T. S. J. F.

Impresso em Londres às custas da Companhia, 1713. Traduzido em 1714.

A obra, que começa por um vivo elogio e uma crítica muito livre de Descartes, liga-se ao grupo numeroso de escritos de todo gênero que se tentou reduzir ao método cartesiano. $\mathrm{O}$ autor coloca, na primeira página, as definições e um axioma. Defende então a geração espontânea. Ele é liberal em política tanto quanto audacioso em ciência e em metafísica. O capítulo mais perigoso para o tempo é o capítulo XIX: Da causa do entendimento, da sabedoria, da razão e da ciência. Tudo veio do jogo dos órgãos, do estímulo das necessidades, e da experiência acumulada. Helvétius não terá nada a inventar.

É possível que Boulainvilliers tenha possuído esse manuscrito: ele buscava as obras audaciosas. Nada autoriza a crer que ele seja o seu autor ${ }^{77}$. Ignoro também se há realmente 
um original inglês, se as datas atribuídas são verdadeiras, ou se não são também somente ficções de prudência.

\section{IV \\ O TRATADO DOS TRÊS IMPOSTORES, O CONDE DE PLELO E O CURA GUILLAUME.}

Fora a exposição da Ética, a mais importante das obras autênticas ou supostas de Boulainvilliers é esta que Barbier menciona sob o título seguinte:

LA VIA ET L'ESPRIT DE M. BENOÎT DE SPINOZA, s. 1., 1719, in-8: que foi reimpresso em 1721 sob o título De Tribus impostoribus, em Francfort-sur-le-Mein, in- $4^{78}$.

A Biblioteca Nacional e a Arsenal contêm uma cópia cada uma do Esprit de Spinoza ${ }^{79}$; a Mazarine o possui sob o título de Traité des Trois Imposteurs ${ }^{80}$. Eu penso que é também essa obra que está conservada em Fécamp ${ }^{81}$. Eu não sei se o ms. de Châlons-sur-Marne ${ }^{82}$ dado como traduzido do latim, e precedido de uma dissertação que atribui o tratado ao Imperador Frederico II, contém o tratado espinosista que existiu somente em francês, ou uma versão francesa do tratado deísta em latim que apareceu sob o mesmo título. Entretanto eu o creria de bom grado como idêntico ao ms. 1193 da Mazarine.

Analisei em outro lugar ${ }^{83}$ o tratado espinosista que apareceu em $1721^{84}$. Os manuscritos da Arsenal e da Biblioteca Nacional dão (ao menos no geral) os mesmos capítulos e o mesmo texto.

Boulainvilliers é o autor do tratado? Ele certamente o possuiu; e é curioso que ele tenha deixado constituir cópias como aquelas da Nacional e da $\operatorname{Arsenal}^{85}$ onde seu Essai de métaphysique está destacado nas duas partes da publicação de 1719, precedida da Vie e seguida do Esprit de Spinosa. A questão seria decidida caso se pudesse sem escrúpulo dar autoridade à rubrica do ms. 2236 da Arsenal: "copiado do original do autor".

Prosper Marchand, que vira muitas cópias da obra na Holanda e na Alemanha ${ }^{86}$, afirmava que ela "corria o mundo em manuscrito há quarenta ou cinquenta anos ${ }^{87, ", ~ e n t a ̃ o ~ d e s d e ~} 1706$ ou $1716^{88}$. Isso não vai de encontro à atribuição a Boulainvilliers, pois que a obra foi copiada de Boulainvilliers em agosto de $1712^{89}$. 
Mas Prosper Marchand acreditava poder, segundo uma cópia manuscrita, atribuí-lo ao "senhor Vrœse, Conselheiro da Corte de Brabant em Haia, da qual Aymon e Rousset corrigiram a linguagem ${ }^{90 "}$. Nós não sabemos seguramente qual autoridade merece a indicação estruturada por Marchand: seria possível que fosse preciso restringir-lhe a aplicação à Vie, e que o Esprit fosse de uma outra mão, Boulainvilliers ou outro.

Se eu ousasse fundar uma conjectura sobre o manuscrito 1193 da Mazarine, eu suporia que Boulainvilliers é o autor da nota $^{91}$ que diz ter recebido a dissertação de La Monnoye; que convencido por este em 1693 da não existência do Tratado dos três Impostores, adquiriu ele mesmo um pouco mais tarde (depois de 1706) a dissertação contrária ao escrito e à carta de Frederico II, a menos que não seja ele que se entreteve a preencher um título vacante e sedutor, tão conforme a suas ideias. Observemos como são compostos certos manuscritos ${ }^{92}$, um dos quais foi copiado em sua casa em $1712^{93}$ : Vie de Spinosa; Essai de métaphysique dans les principes de Spinosa; Esprit de Spinosa. Parece que se quisera constituir assim um verdadeiro curso de espinosismo. No manuscrito 1193 da Mazarine, ao contrário, o Esprit é separado por sua vez da Vie e do Essai: podemos nos perguntar se esse não é o estado mais antigo do Esprit, que é então somente apoiado por suas peças justificativas (verdadeiras ou apócrifas). Enfim, nos impressos a Vie e o Esprit são reunidos: não seria da casa de Boulainvilliers que o manuscrito viera aos editores? Ele teria retido o Essai por prudência, como acusando muito claramente o seu autor. Poderse-ia também pensar que ele o reteve, porque esse escrito era o único que era dele. De quem seria então o Esprit? Eu o ignoro. Mas não vejo nenhuma razão de atribuí-lo ao mesmo autor da Vie. As duas obras não parecem ser chegadas a Boulainvilliers pela mesma via.

Todas essas conjecturas estão muito ao ar.

A propósito do tratado dos Trois Imposteurs, o marquês de Mirabeau na sua Vie inédite du Comte de Plelo ${ }^{94}$ conta uma anedota curiosa:

Plelo ${ }^{95}$ e cinco ou seis de seus amigos pensaram nesse tempo de ser envolvidos em um negócio de uma espécie singular. Um pobre cura do campo contrariado e semelhante ao cervo ingrato que roía a vinha que o colocara seguro da perseguição dos cães, se divertiu em preencher o título desse livro imaginário do qual tanto se falou: De Tribus Impostoribus. Sua obra estava 
dividida em três partes: a primeira destronava Moisés, a segunda perdia o respeito devido à sacra pessoa de Nosso Senhor Jesus Cristo ${ }^{96}$, e a terceira maltratava Maomé. Moisés e Maomé não estavam ali ${ }^{97}$ senão em favor do título; mas quanto à segunda pessoa da Trindade, ele a tomara na mais sincera aversão; ele se dava um trabalho horrível para provar que dois e dois são quatro ${ }^{98}, \mathrm{e}^{99}$ que três não saberiam fazer um. Ele mostrava uma grandíssima erudição, mas muito mal digerida, e, no total, esse livro é mais um emaranhado do qual se pode tirar boas coisas que um livro ${ }^{100}$ curioso por si mesmo. Nessas matérias o raciocínio basta, um infeliz descrente tem o mesmo desvantajoso papel sobre a mesa, que teria uma criança encontrada que quisesse disputar títulos com um homem de uma casa muito antiga ${ }^{101}$.

O senhor Guillaume, munido dessa bela obra e da espécie de mérito que era precisa para tê-la composto, se popularizara ${ }^{102}$ em Paris, onde ele tomava o caminho mais curto para chegar à fogueira. Ele comunicara seu livro a muitas pessoas, e escondia ainda muito mal seus sentimentos na conversa. Plelo curioso ouviu falar disso, ele quis ver $\mathrm{o}^{103}$ livro e o autor, ele ${ }^{104}$ teve ainda a imprudência de comunicar a descoberta que fizera a muitas pessoas, e acabou por ter espécies de concílios ${ }^{105}$ na sua casa com dia marcado onde Guillaume era o presidente. Eu ${ }^{106}$ duvido que adquiriu nesse lugar [algo] do que ornar o processo verbal de sua canonização. Homens ímpios, a mão do Deus de Israel vai se estender sobre vós; mas que fazer às pessoas sobre as quais o espírito infernal soprou seu veneno? Os infelizes olhavam o relâmpago como um vapor da terra cozida pelo sol, eles chegavam até a negar os milagres, diziam que o que o é para nós seria uma puerilidade no ser soberano, que Moisés fazia virar a varinha ${ }^{107}$ quando ele saciou o povo circunciso, que ele fez passar o mar Vermelho durante ${ }^{108}$ o refluxo, que Lázaro conviera com suas irmãs, as quais ${ }^{109}$ Guillaume pretendia ter surpreendido em flagrante delito, que ele imitaria o morto, para tornar-se a segunda ${ }^{110}$ pessoa de um milagre, e que ele se compadecia mesmo, saindo, da umidade do túmulo, que ela lhe dera um reumatismo. Eles queriam enervar até o famoso prodígio que edificou toda a cristandade, e que vi gravado sobre tantos tabernáculos, quando uns judeus tendo apunhalado uma hóstia, dela jorrou sangue na rua, diante do qual umas mulas que passavam se prostraram. Um dos padres do concílio sustentou que tombara somente um mulo que há muito tempo tinha a perna arqueada; mas um outro mais infeliz ainda tomou o partido de negar tudo. De qualquer forma, esperando o julgamento divino, eles tomavam o partido de fazer-se esclarecer vivamente pelos homens ${ }^{111}$.

Guillaume $^{112}$, contente de se ver acolhido por gente ${ }^{113}$ dessa espécie, vangloriava-se muito altivamente, e Moncrif ${ }^{114}$ que eles ali recebiam também ia nas casas narrar $\mathrm{o}^{115}$ assunto de suas assembleias, e nomeava a gente pela qual elas eram compostas.

Problemata: R. Intern. Fil. Vol. 04. No. 03. (2013), p. 382-441 ISSN 2236-8612 
O abade Couet, tão descrente quanto eles, porém mais celerado e hipócrita ${ }^{116}$, fez disso sua corte ao senhor o Cardeal. Felizmente para todos os padres do Concílio, o senhor de Maurepas, cunhado de Plelo, tem o distrito de Paris. O Cardinal the falou do senhor Guillaume como de um homem perigoso que era preciso fazer prender, e disse-lhe que ele tinha assembleias na casa de Plelo, das quais o governo tinha muito motivo para ter inveja, acrescentando que ele não ouvia zombaria $^{117}$ por lá ${ }^{118}$. O senhor de Maurepas, o homem da França que estava mais à mão para uma resposta, respondeulhe sem se espantar que era verdade que a curiosidade levara 0 senhor Plelo a ver o livro do senhor Guillaume, mas que ${ }^{119}$ gente cuja fé não era suspeita tinha visto ${ }^{120}$ essa obra ${ }^{121} \mathrm{sem}$ querer fazer dela um mau uso, em particular Sua Eminência, dentre as mãos da qual ela saia quando passara àquelas de Plelo. Sobre ${ }^{122}$ isso o Cardeal ${ }^{123}$ se adoçou e disse-lhe de absolutamente não ${ }^{124}$ falar do que lhe dissera. Mas ele foi imediatamente a Paris advertir Plelo. Deus sabe o alarme que foi no quarteirão. Cada um começou por colocar os seus papéis as escondidas, e aqueles do Concílio foram levados à casa de La Chevaleraye ${ }^{125}$ que os tem ainda. Foi preciso em seguida procurar o senhor Guillaume; Plelo felizmente o encontrou em Luxemburgo e deu-lhe o alarme tão quente que ele creu ver ${ }^{126}$ já os fardos de lenha organizados ao seu redor. Ele correu a Fresne, sua paróquia, celebrou a Santa Missa para pedir luzes do Santo Espírito ${ }^{127}$ e fez em seguida uma queima geral de todos os seus papéis, reservando alguns sobre os quais ele fizera notas piedosas. Bastou essa pequena ordem acabar que o corpo de cavalaria alcançou a sua casa. "Eh! O que fez o nosso Cura?" diziam os paroquianos assustados: porque ele era de resto atento aos seus deveres, caridoso, regrado na sua conduta, $\mathrm{e}^{128}$ afora o fato de que ele não acreditava em Deus, era o melhor padre do mundo. Mas certo de seu fardo, ele respondeu com tranquilidade $\grave{a ̀}^{129}$ Bastilha onde ele foi conduzido; ele ${ }^{130}$ enfim saiu de lá privado somente da sua cura, $\mathrm{e}^{131}$ enfiou-se-lhe no fundo de uma província com um benefício simples. Pertence bem também a um camponês de Cura de se dar os ares de ser incrédulo.

Eu me perguntei o que havia de verdadeiro nessa história. Ela parece confirmada pelos Arquivos da Bastilha. Étienne Guillaume, cura de Fresnes, entrou na Bastilha em 13 de abril de 1728 e saiu em 13 de fevereiro seguinte. Ele deveu resignar a sua cura e ir-se em exílio à abadia de Hyvernaux perto de BrieComte-Robert ${ }^{132}$. Não se encontrou em sua casa senão um tratado filosófico do ministro Poiret, e algumas peças faceciosas. "Ele de forma alguma é preso por jansenismo, mas por ateísmo", notava o tenente de justiça Hérault ${ }^{133}$. Seus paroquianos sentiam 
sua falta e o reclamaram em vão.

Crer-se-á, caso se queira, que o cura Guillaume foi o autor do Traité, que era evidentemente uma cópia mais ou menos alterada do Esprit de Spinosa. Mas a passagem é muito curiosa por fazer-nos penetrar em uma pequena capela espinosista. Vê-se então se reencontrar, entre 1725 e 1728, um cura da vila como esse Guillaume, um belo espírito como Moncrif, e um cavalheiro como Plelo, para degustar em conjunto o ateísmo. Esse testemunho feito contemporaneamente ao de Duclos sobre as reuniões do café Procope onde se maldizia o Senhor do Ser. Mas as assembleias tidas na casa de Plelo deviam ser mais livres ainda, por serem mais secretas.

Um manuscrito muito análogo e talvez idêntico em fundo ao Esprit de Spinosa e ao Traité des Trois Imposteurs, é assinalado por Prosper Marchand, que o vira na Biblioteca do barão de Hohendorff ${ }^{134}$. Dá-lhe assim o título:

THEOPHRASTUS REDIVIVUS, sive de iis quae dicuntur de Diis, de mundo, de religione, de anima, de inferis et domonibus, de vita secundum naturam et de contemnenda morte: opus ex Philosophorum opinionibus constructum et doctissimis theologis ad diruendum propositum.

Alguns escritos conservados nas duas coletâneas manuscritas da Biblioteca Mazarine nos são dados como fragmentos dessa obra. Um trecho intitulado: DOS MILAGRES, é pretensamente traduzido de um capitulo do Theophrastus redivivus. Um outro se anuncia como uma tradução dos quatro primeiros capítulos do mesmo livro ${ }^{135}$. Um terceiro, intitulado a ALMA MORTAL, ou respostas às objeções que fazem os partidários de sua imortalidade, é igualmente dado como traduzido do Theophrastus redivivus ${ }^{136}$.

Se essas alegações de origem são exatas, existiu um Theophrastus redivivus completamente diferente do Esprit de Spinosa. Mas elas são exatas? Um desses trechos ${ }^{137}$ não é outra coisa que um dos escritos que foram colocados sob o nome de Mirabaud $^{138}$. Seria útil examinar de perto as relações de todos esses trechos manuscritos ou impressos.

\section{V}

\section{UM OFICIAL DE MARINHA FILÓSOFO}

Naigeon publicou em 1768 uma obra intitulada: LE 
MILITAIRE PHILOSOPHE, ou difficultés sur la religion proposées au R. P. Malebranche, prêtre de l'Oratoire, par un ancien officier. Londres, MDCCLXVIII.

"Ele compôs essa obra, diz Quérard, segundo um manuscrito que levava o segundo título: o último capítulo é da mão do barão d'Holbach".

O próprio Naigeon diz, na sua Advertência, que a obra "existia há muitíssimo tempo em manuscrito nas Bibliotecas dos curiosos", e que ele a imprimiu "segundo uma cópia tomada de um manuscrito muito correto, proveniente do inventário do finado Conde de Vence".

A biblioteca Mazarine possui uma cópia ${ }^{139}$ que leva o título indicado por Quérard. Naigeon tomou somente uma parte da obra, a primeira, encurtando-a muito. O texto impresso corresponde às páginas 1 a 125 do manuscrito. As 21 verdades que ali são apresentadas são reduzidas por Naigeon a 18 , ou melhor a 17, porque a décima oitava verdade do Militar filósofo é o capítulo novo redigido, segundo Quérard, por d'Holbach, e ela tomou o lugar da $21^{a}$ verdade do manuscrito que tinha por título: "A profissão de qualquer religião artificial que seja é criminosa".

O Prefácio, que Naigeon retirou, dava algumas vagas indicações sobre o autor, advertindo que se tinha suprimido ou trocado na cópia tudo o que permitisse reconhecê-lo. Com efeito, um outro manuscrito da Mazarine ${ }^{140}$, que é composto de fragmentos destacados da mesma obra, dá algumas informações complementares: essa coletânea de trechos deve ter sido feita a partir do original ou de uma cópia fiel.

Nós aprendemos, tanto de um quanto de outro desses manuscritos, que o autor era um homem de guerra ${ }^{141}$, mais exatamente oficial militar na marinha ${ }^{142}$, que tinha uma grande família, e que deixou uma viúva ${ }^{143}$; que tinha um filho na ocupação de Barcelona enquanto ele escrevia ${ }^{144}$; que ele escrevia então em $1714^{145}$; que ele fora tonsurado em sua juventude ${ }^{146}$; que desde a idade de sete anos, levado em peregrinação por sua mãe a Notre-Dame des Ardilliers, ele fora completamente desencantado ${ }^{147}$; que ele foi devoto e corrompido $^{148}$; que ele serviu nas dragonadas ${ }^{149}$, como tenente ${ }^{150}$; que ele foi a Goa, onde viu a casa dos Jesuítas ${ }^{151}$.

Ele afirma, na carta que serve de Introdução, não ter lido nem Espinosa, "nem nenhum livro de semelhante espécie, nem 
dos socinianos nem dos deístas": nem mesmo Lucrécio ${ }^{152}$.

A coletânea de fragmentos do ms. 1197 parece ter sido constituída por volta de 1730 ou mais cedo ${ }^{153}$.

A obra tal qual se apresenta no ms. 1163 é enorme. Ela se compõe de quatro partes: $1^{\circ}$ um primeiro caderno contendo "o que me fez abrir os olhos", onde é feito um Exame geral das religiões artificiais (é o Militaire philosophe); $2^{\circ}$ uma Réfutation de la Foi, cujo fim anuncia um Examen de la religion ${ }^{154} ; 3^{\circ}$ esse Examen, mais dialético e filosófico que histórico e crítico, e que fala sucessivamente sobre as provas seguintes: os Livros dos Judeus; o Novo Testamento; as Profecias; o estabelecimento do Cristianismo; os Mártires; a Tradição; os Padres e os Concílios; a antiguidade; o consentimento das pessoas ilustres; a dispersão dos Judeus; o maravilhoso efeito do cristianismo; as descobertas dos filósofos cristãos; a santidade do culto; $4^{\circ}$ enfim um $4^{\circ}$ caderno "contendo um sistema de religião fundado metafisicamente sobre as luzes naturais, e não sobre fatos ${ }^{155}$ ".

Terminando, o autor anuncia ${ }^{156}$ que ele medita ainda alguns pequenos tratados, uma Refutação das aparições de espíritos malignos, gênios, diabos, magia e bruxaria, um escrito sobre a origem da idolatria, um outro sobre "o que se pode pensar verossimilmente de Moisés, de Jesus Cristo e de Maomé": o que é justamente o objetivo de um Traité des Trois Imposteurs ${ }^{157}$.

É muito difícil dizer se toda obra é de uma única mão, ou ainda se foi ou interpolada ou alongada ulteriormente. A $3^{\mathrm{a}}$ parte é escrita depois da aparição do Tratado de Bossuet, Politique tirée de l'Écriture sainte ${ }^{158}$, mais exatamente, segundo um outro detalhe $^{159}$, em 1710. O $4^{\circ}$ caderno mesmo é de um contemporâneo de Malebranche, de um homem ainda sob a impressão da sua metafísica e que tenta afastá-la. Malebranche está vivo ou não morreu há muito tempo. Entretanto eu não posso afirmar que a redação seja anterior a 1722 . O título é: " $4^{\circ}$ caderno contendo um sistema de religião fundado metafisicamente sobre as luzes naturais, e não sobre fatos". Não é uma resposta ao abade Houtteville, autor de La Religion prouvée par les faits, que apareceu em 1722? Mas eu direi mais adiante $^{160}$, que se pode crer também que é Pascal que é visado.

De qualquer maneira, é difícil que o texto completo do ms. 1163 não tenha sido constituído no primeiro quarto ou no primeiro terço do século XVIII; e seria razoável examinar primeiro a hipótese de um autor único. 
A obra é claramente racionalista. Ela não atribui nenhum mérito particular ao cristianismo. Ela rejeita o próprio princípio de uma revelação. "Alguns livros e discursos humanos não são

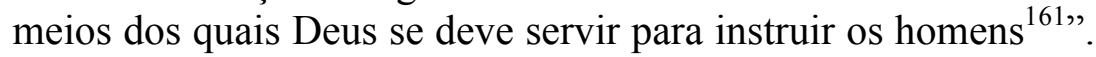
A fé não é um meio de conhecimento: ela consiste somente em "deixar-se levar pelo nariz pelos padres para os seus interesses. E é a mesma coisa em todas as religiões ${ }^{162,}$.

O oficial filósofo demoliu então todas as religiões em geral, depois o cristianismo em particular, depois o método irracional da fé, e ele termina pela exposição do seu sistema de religião natural. Ele é deísta: compreende-se porque Naigeon não quis tomar senão uma parte do manuscrito. Ele admite a espiritualidade, a liberdade, a imortalidade; ele admite as sanções da outra vida, duvidando somente da eternidade das penas, e ele representa a morte por um símbolo que Victor Hugo nos tornou familiar.

E essa palavra de morte bem entendida não significa outra coisa que o instante onde o verdadeiro eu se encontra em um estado simples e natural, como um pássaro cuja gaiola quebramos $^{163}$

Deus é justo, e não é bom, pois ele não pode não ser justo. O mal não saberia ofendê-lo: não se peca contra Deus. Ideia que será cara a Voltaire.

O que pode esperar do homem esse ser infinito? Nada. Não haverá culto então. Um curto catecismo instruirá as crianças sobre a religião natural. Um quarto de hora de meditação por dia representará o essencial ao espírito do homem. Seria bom que o chefe de família fizesse cada dia essa meditação em voz alta, diante de sua família e seus domésticos: ele os exortaria a se examinarem, e a rezar, dessa reza racional que não é um pedido, mas uma adoração. Eis o culto que basta.

Se a filosofia do oficial da marinha não tem nada de muito temerário e, para relacioná-la ao critério do tempo, absolutamente nada de espinosista, em contrapartida seu deísmo é violentamente anticlerical. Naigeon atenuou as suas vivacidades em diversos trechos: e, sob o ponto de vista da cor, é vergonhoso. Eis aqui dois exemplos que bastarão:

\begin{tabular}{c|c}
\multicolumn{2}{c|}{ Ms. 1163} \\
Enfim quando vi que essa santidade tão $\mid$... Quando eu vi, digo, que uma santidade tão
\end{tabular} 
reverenciada (o Papa) era frequentemente um $\mid$ reverenciada era frequentemente o título de um velho velho carcomido de gotas e podre de úlceras que padre, cujo espírito e o corpo estão igualmente seguem as mais infames doenças, dando e enfraquecidos, dando ou refutando tudo segundo o recusando tudo segundo o gosto da avarice de sua gosto da avarice de sua concubina ou de seu concubina, a qual mesmo durante seus prazeres sobrinho $^{166}$.

decidia soberanamente sobre todas as sortes de matérias, encontrando-se assim o oráculo do Santo-Espírito ${ }^{164} \ldots . .$.

...eles [os missionários] imitam os hipócritas, os doces e os modestos esperando para mostrar as garras e os dentes ${ }^{165}$

Eles afetam a humildade, o desinteresse e a submissão esperando para se mostrar tais como são, ou seja, os mais cruéis, etc. ${ }^{167}$

Naigeon preferirá dizer redes ${ }^{168}$ a armadilhas ${ }^{169}$, agricultores $^{170}$ a lacaios $^{171}$ : simplesmente por timidez de gosto, para evitar a brutalidade da palavra particular ou trivial. $\mathrm{O}$ mesmo cuidado, sem dúvida, o conduziu, ainda que não amasse os padres, a retirar ou abreviar as diatribes violentas do oficial contra os altos prelados e os menores e todas as pessoas da Igreja. Nunca mais os Enciclopedistas serão tão enraivados contra a Infâmia: o antigo tenente das Dragonadas nada lhes deixou a inventar sobre esse assunto.

VI

\section{O TENENTE LA SERRE E A OBRA QUE SE LHE ATRIBUI FALSAMENTE}

Em 1761 apareceu, ou melhor reapareceu ${ }^{172}$, um pequeno volume intitulado: Examen de la religion dont on cherche l'éclaircissement de bonne foi, atribué à M. de Saint-Evremond, traduit de l'anglais de Gilbert Burnet. Com privilégio do Rei. Em Londres, por G. Cook, MDCCLXI.

A obra tem 143 páginas, mais um Prefácio assinado J. C. P. D.; ele está dividido em onze capítulos.

Ele foi reimpresso em 1767, com o título seguinte:

Doutes sur la religion, suivies (sic) de l'analyse du traité Théologi-politique de Spinosa par le Comte de Boulainvilliers. Londres, MDCCLXVII.

As Dúvidas ocupam nesse pequeno volume as páginas 154; elas se compõem de quatorze capítulos divididos quase todos em curtos artigos.

Antes de ser impressa, a obra teve uma difusão 
relativamente considerável. As cópias parecem ter sido numerosas, e foram feitas até o início do século XIX ${ }^{173}$. Elas são, como as duas edições, intituladas tanto Examen quanto Doutes, ou ainda Examen ou Doutes.

Encontrei quatro dessas na Mazarine ${ }^{174}$, três na Biblioteca Nacional ${ }^{175}$; uma na Arsenal ${ }^{176}$. Vejo outras dessas em Rouen ${ }^{177}$, em Fécamp ${ }^{178}$, em Châlons-sur-Marne ${ }^{179}$ : pode-se hesitar às vezes, o mesmo título Examen de la religion pertencendo a um extrato da obra que apareceu sob o nome de Fréret ${ }^{180}$.

O ms. 1192 da Mazarine está em quatorze capítulos, como a edição de 1767 , que reproduz a sua ordem, mas geralmente encurtando-a, não sempre.

O ms. 1193 está em onze capítulos cuja ordem não é a mesma que a do ms. 1192, e cujo texto é às vezes mais longo, mas também com alguns desenvolvimentos que faltam no outro. O ms. 1199 da Mazarine, em quinze capítulos, o ms. 2091 da Arsenal, igualmente em quinze capítulos, os mss. 13213-13215 da Nacional, em onze capítulos, e enfim o impresso de 1761, são em substância idênticos ao ms. 1193.

Os três manuscritos da Nacional representam o estado mais antigo da obra. O ms. 1193 insere após o capítulo VI, um Suplemento "tirado, diz uma nota, de um outro manuscrito", e intitulado dos Milagres, que se torna o capítulo VI do ms. 2091 da Arsenal. Enfim o ms. 1193 desenvolve uma curta passagem dos outros manuscritos em um Dialogue entre un Indien et l'Église ${ }^{181}$.

Em que data a obra foi composta?

O ms. 14 de Fécamp tem por título Doutes sur les religions, ouvrage traduit de l'anglais, 1739. Os mss. 1193 e 3564 da Mazarine começam por uma Carta a um amigo do autor, assim datada: "Em Londres, em 14 de maio de 1739, velho estilo". O autor de uma Advertência contida no ms. 1193 da Mazarine diz: "Eu li também um outro manuscrito intitulado Doutes, traduzido do inglês, com uma epígrafe datada de Londres, 1741, servindo de envio". Mas essas datas podem ser fictícias.

O ms. 1192, no Dialogue de l'Indien, dá uma nota do autor que não passou no impresso de 1767 . Esse autor diz ter tirado certos detalhes ${ }^{182}$ de um manuscrito que ele leu em Roma em 1737, e reporta um fato que ele leu em um manuscrito dos Arquivos do Hôtel de Ville de Lyon e recolheu no "Journal de 
ses voyages, ano 1736, vigésimo quinto dia de maio".

O Dialogue é então posterior a 1737. Mas o resto da obra pode ser anterior.

Muitos pretendem, diz a Advertência ${ }^{183}$ do ms. 1193 da Mazarine, que há mais de trinta anos presentemente que essa obra está composta.

E para que a palavra presentemente não deixe dúvida, ele coloca em margem: 1741. O que reconduziria a 1711 a composição da obra.

Uma data extrema seria, em todo caso, fornecida pela primeira impressão feita em Trévoux (ou seja Holanda) em 1745: eu não a vi. Mas Quérard e a Advertência do ms. 1193 da Mazarine atestam a sua existência.

Segundo essa Advertência, a obra manuscrita foi denunciada como perigosa pelo abade Molinier e pelo abade Gaultier. Eu não pude ver os Discours do Padre Molinier contre les impies du temps: mas eles são de 1734. O abade Gaultier, em "o Poema de Pope intitulado Essai sur l'homme convaincu d'impiété" (la Haye, 1746, in-12), diz que tem sob os olhos, escrevendo a sua primeira carta (datada de 6 de setembro de 1745), "um manuscrito magnificamente encadernado que leva por título: Examen sur la religion en général dont on cherche l'éclaircissement de bonne foi, 1741, en onze chapitres".

Torna-se então bastante possível de aceitar a data da carta de envio do ms. 1192 da Mazarine, e de crer a obra acabada em 1739. Ela pode mesmo ser anterior de alguns anos.

Mas qual é o autor ${ }^{184}$ ? A Advertência do ms. 1193 da Mazarine diz que se atribuiu o livro a Saint-Évremont cujo nome, com efeito, encontra-se em diversos manuscritos ${ }^{185}$, a Mirabaud, a Mallet ${ }^{186}$, a Boulainvilliers, a d'Argens; É dado às vezes como traduzido do inglês ${ }^{187}$, e mais precisamente de Burnet $^{188}$.

\footnotetext{
É mais, continua a Advertência, do senhor de Serres, oficial das guardas francesas e em seguida a serviço dos Estados gerais, que o admitiu enquanto morria; seu arrependimento e sua retratação se encontram na Bibliothèque raisonée (fol. 41, $2^{\mathrm{a}}$ Parte, in-8, Copenhague, 1479, p. 467), onde ele é ligeiramente e mal refutado, e somente em bagatelas; de resto diz-lhe aqui muitas injúrias sem provas, e se o admite perigoso.
}

Há com efeito na Bibliothèque raisonée ${ }^{189}$, p. 41, out.- 
dez.1148, p. 475, uma carta datada de Maëstricht, 10 de outubro de 1748, e assinado de Vernède, pastor da Igreja Wallonne nessa cidade.

Esse Vernède conta que "pouco tempo antes da ocupação de Maëstricht" (logo, antes de 13 de abril de 1748), ele foi chamado junto ao senhor de la Serre, "anteriomente tenente da Companhia livre do Senhor Cavaleiro de Vial". Ele o encontra "penetrado de tristeza com a ideia dos pecados que ele cometera", e sobretudo "desolado" de ter "composto alguns escritos contra a religião".

La Serre estruturou então em 10 de abril uma declaração que ele encarregou Vernède de tornar pública, e que aquele enviou à Bibliothèque raisonée, para retratar e condenar seus escritos perigosos:

$1^{\circ} \mathrm{O}$ livro onde se reconhecem as dúvidas sobre a religião;

$2^{\circ}$ Uma obra manuscrita sobre a natureza da alma;

$3^{\circ}$ Umas cartas sobre os costumes e caráteres dos diferentes estados que compõem a França;

O jornal nos adverte

que o manuscrito sur la nature de l'âme foi queimado; que os outros não estão impressos ainda e que há razão para esperar que não o serão jamais.

Mas da própria declaração de La Serre, eu acredito que ele não é o autor das Doutes. Eis aqui os seus termos:

Eu declaro que a sequência de um livro intitulado Les Sentiments de Monsieur Guillaume Burnet sur la religion, ou examen de la religion par $M$. de Saint-Évremond, da qual eu sou o autor, é o fruto de uma imaginação esquentada e avivada pela libertinagem.

Resulta desses termos que La Serre não escreveu as Doutes, mas uma Sequência às Doutes. Quérard e o autor da Advertência leram muito rápido.

O autor das Doutes ou Examen resta então por descobrir. Quem quer que seja, não é preciso buscar do lado de Boulainvilliers. Não é um espinosista; o abade Gaultier a bem dizer, é um deísta ${ }^{190}$. Ele é de resto violento contra as religiões, a Igreja e os mínimos. Ele demonstra, segundo Bayle, "que a religião católica não é necessária à sociedade civil, que ele tende 
a destruí-la e a reter nos legítimos limites menos pessoas do que se pensa ${ }^{191,}$.

A obra deveu ir, por sua vez, se enriquecendo de tons acentuados. Os três manuscritos da Nacional acabam com uma profissão de fé deísta:

Sim, meu Deus, falais. Vosso servidor escuta. Notam fac mihi viam, in qua ambulem ${ }^{192}$, como fala o Profeta, e eu a seguirei com toda a submissão e todo o respeito que devo a meu criador e soberano mestre ${ }^{193}$.

E eis as últimas palavras do manuscrito da Arsenal:

... A razão e a natureza são as obras de Deus, e as religiões as dos homens; e [de] nossos pais foram assaz simples por juntar fé a esses pios charlatães e a esses astutos devotos que, com seus sagrados turnos de passe-passe, fizeram deles como uns macacos, para gozar deles em seus particulares, logo que com tanta devoção eles os virão rastejar diante deles, e fazer-lhes dar tudo o que eles tinham de melhor, prometendo-lhes o que não estava de modo algum em poder deles lhes dar.

Era essa a conclusão do manuscrito de 1741 que o abade Gaultier tinha sob os olhos ${ }^{194}$.

\section{VII \\ LEVESQUE DE BURIGNY}

Conhece-se a obra intitulada:

EXAMEN CRITIQUE DES APOLOGISTES DE LA RELIGION CHRÉTIENNE, par M. Fréret, secrétaire perpetuel de l'Académie royale des inscriptions et belles-lettres, MDCCLXVII ${ }^{195}$.

São 13 capítulos muito fortes de erudição e de raciocínio, onde as diversas teses da apologética são refutadas e onde são colocadas as principais objeções da filologia e da história.

Quérard ${ }^{196}$ demonstrou que o verdadeiro autor da obra era Lévesque de Burigny, o autor da Théologie payenne (1745, 2 vol. in 12). No primeiro desses escritos, o muito douto Burigny se esforçava para estabelecer que faltava base à crença na religião cristã; no outro, que o cristianismo não trouxera nada de novo, nem no seu dogma ${ }^{197}$ nem na sua moral. As duas obras convergiam. As aproximações de detalhes feitas por Quérard 
mostram bem que elas partem da mesma mão.

Entre as numerosas dissertações que Burigny apresentou à Académie des Inscriptions, há uma "sobre as obras apócrifas supostas nos primeiros séculos da Igreja ${ }^{198}$ ", que foi lida em $1^{\circ}$ de março de 1757. É uma longa enumeração, toda objetiva e de tom irreprochável, das suposições e das falsificações feitas pelos pagãos, pelos heréticos e pelos ortodoxos: a sua substância se encontra no Examen des apologistes.

Sabe-se por outro lado que Burigny fizera uma grande obra sur la Vérité de la religion, em favor da religião natural e contra as religiões reveladas.

\footnotetext{
O manuscrito dessa obra, conservado nos papéis de família, diz o abade Genét ${ }^{199}$, não contava menos de 1595 meiaspáginas in- $4^{\circ}$ e fora terminado em 11 de setembro de 1733 .
}

Jean-Simon Lévesque de Pouilly, sobrinho de Burigny, reconhecera uns capítulos desse manuscrito no Examen publicado sob o nome de Fréret $^{200}$.

É provável que Burigny tenha feito ele mesmo esse extrato em treze capítulos, e o fez pouco tempo após ter terminado seu grosso manuscrito. Lê-se aqui ${ }^{201}$ que um escrito de 1725 foi feito há pouco, que se acabou de ver ${ }^{202}$ os milagres do diácono Pâris ${ }^{203}$; o autor se refere ${ }^{204}$ a sua Histoire de la philosophie païenne (1724), e não à edição revista e aumentada que ele deu depois (1745) sob o título de Théologie païenne. $\mathrm{O}$ texto que foi impresso é então muito pouco posterior a 1730 e sensivelmente anterior a 1745.

As cópias circularam sem dúvida muito cedo. Aquela da Biblioteca Nacional $^{205}$ é datada de 1754: ela é quase conforme à edição. Uma outra cópia sem data se encontra em uma coletânea da Mazarine ${ }^{206}$, com as Recherches sur l'origine du despotisme oriental (de Boulanger) e a análise do tratado TheologoPoliticus (de Boulainvilliers): ela é intitulada Histoire critique du christianisme ou Examen de la religion chrétienne, de $M$. Fréret. Uma cópia que está na $\operatorname{Arsenal}^{207}$ tem por título: Établissement du christianisme ou Réflexions critiques sur les arguments employés pour prouver la religion chrétienne. Châlons-sur-Marne possui duas cópias dela ${ }^{208}$.

Um extrato mais curto e menos erudito circulou, englobando somente os capítulos XII e XIII da impressão de 1767. Eu não sei se esse extrato foi tirado do precedente, ou diretamente do manuscrito completo. Encontro uma cópia dele 
na Mazarine ${ }^{209}:$ Examen de la religion en 14 chapitres (em 8, na realidade); uma outra na Arsenal ${ }^{210}$, uma outra em Châlons-surMarne $^{211}$, todas as duas sob o título: De l'examen de la religion. Enfim um extrato unicamente do capítulo XIII se encontra no mesmo manuscrito da Arsenal ${ }^{212}$.

Esse manuscrito da Arsenal é uma coletânea composta de 7 peças: $1^{\circ}$ o Examen de la religion que nos ocupa; $2^{\circ}$ das Réflexions sur l'existence de l'âme et sur l'existence de Dieu; $3^{\circ}$ um Traité de la liberté; $4^{\circ}$ uma Lettre sur M. Locke; $5^{\circ}$ uma carta sobre o Argument de M. Pascal et de M. Locke, etc.; $6^{\circ}$ um suplemento a essas reflexões, que é o $13^{\circ}$ capítulo do Examen impresso; $7^{\circ}$ dos Sentiments des philosophes sur la nature de $l^{\prime} \hat{a}^{2} e^{213}$, pequeno escrito espinosista que é feito somente para destacar e apoiar a opinião de Espinosa sobre a alma. Logo os números 2, 3, 5, 7 foram impressos em 1743 nas Nouvelles libertés de Penser; a carta sobre Locke é a primeira redação da $13^{\mathrm{a}}$ carta filosófica de Voltaire que foi impressa após 1738 e frequentemente reimpressa; as duas outras peças são os extratos de Burigny. das edições ${ }^{214}$

O texto da carta sobre Locke parece bem anterior àquele

É então bastante verossímil que a coletânea da Arsenal tenha sido constituída antes de 1743 , e mesmo antes de 1738 , ou que, se o próprio manuscrito foi executado posteriormente a essas duas datas, ele é a cópia de uma coletânea cujo estabelecimento lhe é anterior.

\section{VIII \\ FRÉRET}

Se é preciso atribuir a Burigny o Examen critique, não se pode retirar de Fréret uma obra perfeitamente incrédula:

LETTRE DE THRASYBULE A LEUCIPPE, s. 1. n. d. (por volta de 1768).

Foncemagne assegurou a sua autenticidade ao senhor de Sainte-Croix ${ }^{215}$. Naigeon a reimprimiu, retocando-a, parece, muito acentuadamente o texto, no seu artigo FRÉRET da Encyclopédie Méthodique (Philosophie ancienne et moderne, $\mathrm{t}$. II); o encontramos também no tomo XX das EUVRES de Fréret.

É difícil de não reconhecer aqui a obra da qual Duclos fala nas suas Mémoires ${ }^{216}$ : 
Ele fizera uma obra que seria perigosa, se estivesse ao alcance do leitor comum. Teria sido muito triste que se tornasse pública. Tenho por prova disso a carta que ele me escreveu e me enviou algum tempo depois que eu me tornei seu confrade ${ }^{217}$ na Académie des Belles-Lettres. Ele me marcava no seu bilhete, que eu guardei para sua justificativa, se alguém traísse a sua confiança, que essa obra não era senão para alguns amigos interioris admissionis.

A obra se difundiu muito. Naigeon ${ }^{218}$ diz ter visto mais de vinte manuscritos dela; e Thieriot, sabendo que ela circulava no exterior, diz que dela havia em Paris "alguns manuscritos em número muito grande ${ }^{219}$,.

Eu vi uma cópia sua na Nacional ${ }^{220}$, uma na Mazarine ${ }^{221}$, uma na Arsenal ${ }^{222}$; Existe uma em Douai ${ }^{223}$, uma em Rouen ${ }^{224}$.

Uma nota do ms. 1193 da Mazarine fala que se crê que Fréret a escreveu "à sua irmã, religiosa plena de espírito, morta há pouco em um convento a algumas léguas de Paris". Ela pretende que essa cópia era a única que existia em 1750 (ou seja, à morte de Fréret $^{225}$ ). "Outros asseguram tê-la lido em 1723". Naigeon diz também: "Parece que ele a escreveu em 1722 "226".

Uma outra nota de uma mão diferente no mesmo manuscrito, escrita após 1756, diz que "esse manuscrito há quatro ou cinco anos se multiplicou muitíssimo, infelizmente para a religião cristã". O autor duvida que Fréret fosse capaz de escrever essa carta plena de metafísica; ele crê que somente a primeira parte é dele.

Essa primeira parte é uma critica das religiões; a segunda trata da natureza e da origem dos conhecimentos humanos, do meio de distinguir aquelas que são certas e claras; a $3^{\mathrm{a}}$ expõe o que a razão fundada sobre a experiência nos ensina sobre a essência de Deus, a alma e a religião em geral. A obra é muito viva contra o cristianismo, e contra todas as religiões que são colocadas no mesmo plano. Ele não poupa nem a moral cristã. $\mathrm{O}$ autor é sensualista, reduz Deus ao fatum, e não o distingue do universo, o que parece bem ser uma opinião espinosista. Ele coloca a virtude no amor do bem social. Ele não crê na imortalidade da alma, mas vê nisso um erro útil. 


\section{IX \\ DUMARSAIS}

Um outro incrédulo confirmado foi o gramático Dumarsais. Temos diversas passagens sob o seu nome nas coletâneas impressas; as Nouvelles libertés de Penser (1743) dão dele um pequeno escrito, o Philosophe; Naigeon o reimprimiu em 1770 no seu Recueil philosophique, com uma outra peça, De la Raison.

Pretende-se que ele tenha feito uma Analyse des quatre religions qui ont eu le plus de sectateurs; um fragmento dela foi publicada por Voltaire no Recueil nécessaire em 1765, sob o título: ANALYSE DE LA RELIGION CHRÉTIENNE PAR DUMARSAIS.

É difícil de afirmar ou negar essa atribuição. Ela não tem, em todo caso, nada de contrário aos sentimentos de Dumarsais, que se fez, sabe-se, o editor de Mirabaud um pouco malgrado esse autor, e que foi escolhido pelo incrédulo Président de Maisons para fazer a educação estritamente racionalista do seu filho.

A Analyse de la religion chrétienne é muito curta e dividida em 4 capítulos: ela oferece uma vulgarização dos principais argumentos da crítica exegética e racionalista contra os dois Testamentos e o valor que lhe é atribuído pela ortodoxia. A obra é posterior à Religion chrétienne prouvée par les faits do abade Houtteville (1722). A conclusão é deísta.

Conheço duas cópias dele na Mazarine ${ }^{227}$ : uma, aquela do ms. 3564, leva o título falso: L'HOMME MACHINE, em Leiden, MDCCXLVIII, que ao menos indica após que data ela foi feita, e ela contém, sob esse título, dois escritos: $1^{\circ}$ Discours préliminaire, sur le Déisme ou Doutes d'un homme qui examine et veut s'éclaircir (cf. p. 293); $2^{\circ}$ la Religion chrétienne analysée por C.F.C.D.F. A outra, aquela do ms. 1196, Analyse de la religion chrétienne por M...., com notas, deve datar do início do século $\mathrm{XIX}^{228}$. Eu constatei que havia ainda três cópias em Rouen $^{229}$, uma em Fécamp ${ }^{230}$, uma em Montivilliers ${ }^{231}$.

Muitos desses manuscritos são datados: o de Montivilliers, de 1748; um de Rouen (1571), de 1749; o de Fécamp, 1754. O autor é designado pelas iniciais C.F.C.D.F. no manuscrito de Montivilliers, e no ms. 3564 da Mazarine; pelas iniciais C.F.C.D.T. no ms. 1571 de Rouen.

$\mathrm{O}$ texto dos dois manuscritos da Mazarine é mais 
completo que o texto impresso em 1765: assim, é somente à página 27 do ms. 1196 que se encontra a frase inicial da impressão: "Eu percorri primeiro os livros de Moisés". O detalhe do desenvolvimento comum é mais extenso também nos manuscritos, as referências mais numerosas e a conclusão menos concisa.

Eu notei no ms. 3564 uma alusão aos milagres do diácono Pâris - que eram, segundo d'Alembert ${ }^{232}$, uma das duas coisas (a outra era o sistema de Law) pelas quais Dumarsais se felicitava por ter vindo ao mundo em sua época - e à defesa que a seu respeito publicou Carré de Montgeron $(1737-1741)^{233}$. O ms. 1196 cita os discursos de Woolston sobre os Milagres ${ }^{234}$, os Amusements philosophiques do P. Bougeant Sur le langage des bêtes (1739), e uma Instruction pastorale de 1736 do bispo de Montpellier.

O texto do ms. 1196 é certamente posterior àquele do ms. 3564: introduziu-se na sua conclusão uma alusão ao livro dos Moeurs de Toussaint (1748). Poderia ser que o impresso mais curto que todos os dois fosse mais conforme à obra original.

Os dois manuscritos juntam à Analyse umas notas de um outro autor. Aquelas do ms. 3564 são mais amplas e mais numerosas que aquelas do ms. 1196: elas têm provavelmente uma origem comum. Eu destaco em uma delas ${ }^{235}$ uma alusão aos Pensées philosophiques de Diderot $(1746)^{236}$.

Pode-se concluir, creio, que a composição da Analyse se situa entre 1722 e 1740, com adições ou interpolações que não são posteriores a 1747, data na qual a obra parece ter todo o seu desenvolvimento.

Precocemente, ele fora julgado curto, rápido e muito sumário por certos leitores, e a ele se adicionaram copiosas justificações. O ms. 1193 (2) da Mazarine nos oferece a Addition des preuves citées dans la Religion chrétienne sans y être rapportées, par $A B C, 1749$, e a cópia de Montivilliers faz seguir o escrito de C.F.C.D.F. (1748) da Addition des preuves qu'il a seulement indiquées par ABCD, son prosélyte (1749). Talvez seja também esse suplemento que se encontra na cópia de Fécamp em duas partes e dois volumes com adições e correções. Eu reencontrei o mesmo escrito, ao menos em essência, na primeira peça do ms. 1189 da Mazarine: La foi anéantie, ou démonstration et la fausseté des faits principaux qui sont contenus dans les deux Testaments, ouvrage traduit du latin de Hobbes, $1763^{237}$. 
O ms. 1193 remete $^{238}$ ao tomo I do Spectacle de la nature do abade Pluche: a composição desse escrito se situa então entre 1732 e 1749, mais perto sem dúvida de 1749 .

\section{$\mathbf{X}$ \\ MIRABAUD}

O ms. 2091 da Arsenal leva o título reconfortante sobre o qual falei no início dessas notas: Existence de la foi chrétienne. Uma mão desconhecida escreveu sobre a folha de guarda ${ }^{239}$ : "é preciso mesmo tomar cuidado para não se enganar com o título desse volume. Ele parece feito em favor da religião, mas no fundo ele a ataca em todas as suas partes, etc.".

Esse título cobre uma coletânea de três obras temerárias: o segundo é a Opinion des anciens sur la nature de l'âme, e o $3^{\circ}$ o Examen de la religion en quinze chapitres, do qual falei mais acima $^{240}$. O primeiro, por excesso de precaução, expõe o belo título: Motifs pressants pour exciter la foi des chrétiens et pour leur en faire fréquemment produire les actes.

A obra preenche 235 fólios.

$\mathrm{Eu}$ encontro as duas primeiras peças do manuscrito da Arsenal em ordem inversa no ms. 3561 da Mazarine. O título Motifs pressants, etc., é conservado.

A primeira parte dos Motifs pressants forma o primeiro escrito de uma coletânea da Nacional ${ }^{241}$, com o título: Examen critique du Nouveau Testament.

Essa primeira parte é, como o indica esse último título, uma crítica dos fatos da vida de Jesus Cristo, seguido de uma crítica dos dogmas ${ }^{242}$.

Na segunda parte, que o manuscrito da Nacional não dá, o autor trata dos Judeus, em cinco capítulos: Opinion des anciens sur les Juifs; État de la Judée au temps de Jésus-Christ et depuis jusqu'à la ruine de Jérusalem; Caractères, sectes et opinions des Juifs; Sectes des Juifs; Du Messie ${ }^{243}$.

$\mathrm{O}$ tom é muito frequentemente leve e irônico. $\mathrm{O}$ autor faz dizer por um filósofo aos cristãos:

A moral de vosso Messias me parece bela, eu a acho conforme àquela que ensinaram todos os homens razoáveis que apareceram sobre a terra mais de 400 anos antes dele. 
Ele espinafra a simplicidade de espírito necessária para crer nos milagres, nas promessas, nos ensinamentos do Salvador e seus próprios raciocínios que não eram sempre de muito valor. $O$ fundo da crítica dos Evangelhos agrega as mesmas dificuldades sobre as quais Burigny, Dumarsais, o oficial filósofo, o autor das Doutes, insistem igualmente.

A segunda parte, sobre os Judeus, parece ser idêntica à tradução dos quatro primeiros capítulos do Theophrastus redivivus contida no ms. 1195 da Arsenal ${ }^{244}$.

A Opinion des anciens sur la nature de l'âme, que acompanha os pseudo-Motifs pressants no ms. 2091 ${ }^{(2)}$ da Arsenal e o $n^{\circ} 3561^{(1)}$ da Mazarine, se reencontra no $n^{\circ} 3560 \mathrm{da}$ Mazarine. Eu a encontro ainda em um manuscrito de Rouen ${ }^{245}$, onde ela precede a Opinion des anciens sur les Juifs, que parece mesmo ser o começo da $2^{\mathrm{a}}$ parte dos Motifs pressants.

É difícil de não reconhecer Mirabaud como autor desses escritos. Em 1740, J.-Fr. Bernard, nas Dissertations mêlées sur divers sujets importants et curieux (2 vol. in-12), publicou dois fragmentos Sur l'origine du monde e Sur l'immortalité de l'âme, que reaparecem desenvolvidas na edição dada por Dumarsais e Le Mascrier: "LE MONDE, SON ORIGINE ET SON ANTIQUITÉ, $I^{\text {re }}$ partie ${ }^{246}$; DE L'ÂME ET DE SON IMMORTALITÉ $^{247}, 2^{e}$ partie; Essai sur la chronologie, $3^{e}$ partie, Londres, 1751, in-8".

Em 1740 também, J.-Fr. Bernard dava em sua coletânea uma Lettre sur le mépris dans lequel les Juifs sont tombés que se encontrava bastante aumentada nas Opinions des anciens sur les Juifs, publicadas por Naigeon em 1769 (Londres, in-8). Naigeon a ela acrescentava umas Réflexions impartiales sur l'Évangile. Esses dois escritos são justamente as duas partes dos pretensos Motifs pressants.

Uma indicação para datar os Motifs pressants é fornecido pela publicação de J.-Fr. Bernard. A obra completa estava suficientemente difundida em cópias manuscritas no meio do século, para que o abade G. Gauthier cresse dever então respondê-la na sua Réfutation du Celse moderne, 1752.

Os Sentiments des philosophes sur la nature de l'âme, que se encontram no ms. 2557 da Arsenal, são diferentes da Opinion des anciens sur la nature de l'âme. Eles foram impressos com muitos outros fragmentos da mesma coletânea em $1743^{248}$. Eu ignoro se é preciso também atribuí-los a Mirabaud. 


\section{XI \\ FRAGMENTOS DIVERSOS}

Encontro ainda nos manuscritos que examinei diversos fragmentos que podem datar da primeira metade do século XVIII. Eis aqui alguns:

1. La religion chrétienne combattue par ses propres principes où l'on démontre sa fausseté par ses contradictions avec elle-même, par l'auteur de l'Examen des apologistes, $M$. De Saint-Hyacinthe . $^{249}$.

Obra violenta e erudita, feita unicamente com textos eclesiásticos, dirigida contra o número e a riqueza dos padres e dos mínimos e contra a ambição da Igreja: Não seria um outro fragmento da grande obra de Burigny?

2. Des oracles, acompanhando geralmente ${ }^{250} \mathrm{o}$ fragmento sobre os Milagres que é pretensamente tirado do Theophrastus redivivus ${ }^{251}$.

3. Lettre d'un médecin arabe à un fameux professeur de l'Université de Halle en Saxe sur les reproches faits à Mahomet. Traduit de l'arabe, $1713^{252}$

4. Réflexions d'un philosophe sur la divinité, sur le monde et sur la nature de l'homme. Traduit du latin imprimé en $1717^{253}$.

Tratado deísta, sensualista, materialista, pouco favorável aos reis e aos magistrados, animado pela nostalgia do comunismo natural e primitivo. temps-là.

5. Dialogue sur l'âme. Par les interlocuteurs. En ce

Posterior às Lettres Persanes. O autor reclama a reforma da Igreja, o retorno dos padres à sociedade, e o casamento civil. Uma primeira parte é composta de sete Diálogos, onde tomam parte um Fariseu, um Saduceu, um cura francês, um cristão e um filósofo. Uma segunda parte contém uma exposição direta onde o cristianismo é criticado na sua história, seu dogma e sua moral: a conclusão é que é um sistema puramente humano, que somente o desejo de evitar as revoluções permite conservar.

6. Discours de Woolston sur les miracles ${ }^{254}$. É um abreviado; o original foi publicado em Londres em 1727-1728.

7. Parallèle entre Mahomet et Moïse le grand libérateur des Juifs, par Zelim le musulman, dans une lettre qu'il écrit à Nathan rabbin ${ }^{255}, 1731$. 
Muitas coletâneas manuscritas parecem mesmo ter sido constituídas antes de 1750: assim as ${ }^{\text {os }} 1193,1194,1195,2235$, 3560, 3561, da Mazarine: 2091 e 2557 da Arsenal, etc. Eu já analisei o conteúdo da 2557 da Arsenal. Eis como a n 1194 da Mazarine é composta:

$1^{\circ}$ Dissertation et preuves de l'éternité du Monde. Posterior a 1701; anterior ao terremoto de Lisboa.

$2^{\circ}$ Dialogue entre un Français et un Algérien sur leurs religions. Escrito deísta.

$3^{\circ}$ Extrait de l'ouvrage intitulé Doutes ou objections de Th. Burnet sur le $1^{\text {er }}$ chapitre de la Genèse, conciliés avec l'Écriture par M. $D^{* * *}$. - Extrait de la théorie sacrée de la terre $^{256}$ et des révolutions et changements de notre globe, traduit du latin de Th. Burnet et concilié avec l'Écriture par M. D***.

$4^{\circ}$ Traité des Miracles.

$5^{\circ}$ Traité des Oracles. Ver mais acima sobre esses dois tratados. O segundo parece derivado de Van Dale ou de Fontenelle: ele é do mesmo autor que o precedente.

$6^{\circ}$ Dissertation sur le Messie où l'on prouve qu'il n'est pas encore venu et que, suivant les promesses des prophètes qui l'ont annoncé aux Israélites, ils attendent avec raison.

$7^{\circ}$ De la conduite qu'un honnête homme doit garder pendant sa vie ${ }^{257}$.

$\mathrm{O}$ autor reconhece aqui somente a virtude social, prega o respeito ao costume de cada país em matéria de religião, faz o elogio dos incrédulos que foram pessoas honestas, de Epicuro a Espinosa e de Martin (ou melhor Mathias) Knutzen de Holstein às cartas da China. Ele conclui que as religiões não contribuem em nada para fazer o verdadeiro homem honesto.

É o estado de espírito que não é mais muito raro ao fim do século XVII e ao início do XVIII. Falando de Martin Knutzen, cuja seita se difundiu a partir de $1673^{258}$, o autor se serve da expressão: de nossos dias ${ }^{259}$.

Essas coletâneas são inteiramente análogas às Dissertations mêlées publicadas em 1740 por J.-F. Bernard, e às Nouvelles libertés de Penser de $1743^{260}$; é muito possível que os dois impressos não tenham sido constituídos por seus editores de peças até então esparsas, mas que tenham simplesmente reproduzido algumas coletâneas manuscritas que já circulavam.

Eis aqui bastante em todo caso para provar a atenção que merecem esses manuscritos, logo que se quer fazer a história do pensamento filosófico antes de 1750. Mesmo circundando os 
grandes escritores tais quais Fontenelle, Voltaire e Montesquieu, algumas obras de segunda e terceira ordem, uns Terrasson e uns Deslandes, não se tem de forma alguma uma visão clara e completa do movimento. É preciso ir pesquisar os impressos tardios como o Extrait de Meslier, o Militaire philosophe e o Examen des apologistes. E esses impressos tardios dão somente uma tênue ideia do que os manuscritos revelam. A resistência do poder às ideias novas remetia as coisas, para os inovadores que não tinham a sede do martírio, ao estado onde elas estavam antes da invenção da prensa. É nos manuscritos que é preciso ir buscar o pensamento perigoso e novo que circulava.

A força das duas correntes de incredulidade, ateu e deísta, somente aparece bem por eles: ainda não vi senão algumas amostras. Descobre-se aqui, notadamente, uma violência de sentimentos e de expressões que surpreende. Encontra-se, já constituído e pronto para o uso, todo o arsenal dos argumentos críticos, históricos e filosóficos contra a religião e a espiritualidade ou imortalidade da alma: parece - mas seria algo a se examinar - que Voltaire não tivera senão que ali se fornir ${ }^{261}$.

\section{XII \\ A DIFUSÃO DO ESPINOSISMO E A PREPARAÇÃO DO ANTI-PASCAL}

Diversos pontos mereceriam um estudo particular. Seria útil estabelecer o inventário de todas as dificuldades particulares cultivadas, nos manuscritos ou nos impressos, contra a história, o dogma e a moral do cristianismo. Isso nos levaria a conhecer as fontes da erudição e da crítica desses incrédulos, e a compreender também o que eles transmitiram a Voltaire, a d'Holbach e a seus contemporâneos.

Seria importante evidenciar com afinco em todos os manuscritos que se pode encontrar as expressões ou os traços do espinosismo. A difusão do espinosismo é ainda muito mal conhecida. Os filósofos que se ocuparam de Espinosa ${ }^{262}$ procuraram naturalmente sua influência em escritos filosóficos, eu quero dizer especialmente e formalmente filosóficos e sobretudo metafísicos. Afora Boulainvilliers e Mairan, eles não indicam grande coisa. Seria preciso buscar nos tratados de polêmica irreligiosa como são alguns desses que eu examinei aqui, e nos documentos que nos conduzem fora do mundo 
profissional dos filósofos, em meio mesmo à sociedade mundana. Encontrar-se-ia então formas do espinosismo mais ou menos degradadas e compactadas do ponto de vista dos filósofos, mas vivas e práticas, e por isso interessantes ${ }^{263}$.

Aos tratados estudados por Colona d'Istria, é preciso acrescentar L'Esprit et la vie de Spinosa, ou melhor o Traité des Trois Imposteurs (em uma de suas duas formas principais); este nos leva ao cura Guillaume, ao Conde de Plelo e a seus amigos. De outra parte, o cura Meslier é claramente espinosista, como o autor dos Sentiments des philosophes sur la nature de l'âme. Fréret, que por outro lado sofreu em sua juventude a influência de Boulainvilliers, e Mirabaud provavelmente o são também: esses nos levam ao café Procope, onde eles encontram Dumarsais, Boindin, Terrasson, La Motte. Duclos, que também o frequentava, nos ensina ${ }^{264}$ que ali se chamava Deus de Senhor do Ser, nome que sente forte o espinosismo. Dumarsais, malgrado a conclusão deísta da sua Analyse, é um ateu, o que quer dizer, nesta data, geralmente um espinosista.

Antes de todos esses, na ordem cronológica, seria preciso situar um amigo de Saint-Évremont e de Bayle, o Dr. Morelli, médico de Madame de Sandwich, grande viajante e que sabia todas as línguas ${ }^{265}$. Saint-Évremont ${ }^{266}$ o denuncia claramente como espinosista, e Desmaizeaux, nas notas da Correspondance de Bayle ${ }^{267}$, nos diz que fora ligado com o cavaleiro de SaintGlain, o tradutor do Tractatus theologo-philosophicus.

Seria útil ver de perto, para nele reconhecer o espírito e as ideias, as diversas sociedades da primeira parte do século XVIII onde domina a incredulidade: os grupos que têm por centros Boulainvilliers, Rémond le Grec, o médico Falconet ${ }^{268}$, o círculo dos Caumartin, o salão de Madame Doublet. Nós temos muitas anedotas e poucos conhecimentos precisos sobre todo esse mundo.

Um outro ponto interessante seria encontrar o curso onde se situam as Remarques de Voltaire sur Pascal ${ }^{269}$. Parece-me que após trinta a quarenta anos, quando apareceram, os livrespensadores estavam assombrados pela ideia de demolir a Apologia esquematizada nos Pensées de Pascal. Isso se explica facilmente: era o forte dos crentes, e os apologistas ulteriores, Abadie, Houtteville, dali tiravam seus métodos e seus argumentos.

Um fragmento de Saint-Évremont, sur les Plaisirs ${ }^{270}$, endereçado ao conde de Olonne, é provavelmente anterior à 
publicação dos Pensées e talvez contemporâneo de sua redação: é uma aceitação do divertimento, que, longe de ser um signo de miséria, torna-se um meio de escapar à miséria. Saint-Évremont contradiz Pascal provavelmente sem conhecê-lo.

Mas Boulainvilliers leu Pascal, e volta sua análise da Éthique contra ele. É nos Pensées que ele pensa quando escreve $^{271}$ :

"Nossos desejos refletidos devem se multiplicar, na proporção de nossa sensibilidade, com o número e a quantidade dos objetos que lhe fazem impressão: o que responde naturalmente ao argumento tirado de uma pretensa insaciabilidade do coração humano, em consequência da qual se supõe que ele não pode jamais ser satisfeito senão pela possessão de um objeto infinito... Mas se é verdade, como não saberíamos duvidá-lo, que nós somos seres sensíveis, engajados em formar perpetuamente novos pensamentos e novos desejos, por ocasião de cada nova percepção: como a satisfação dos primeiros desejos não determina absolutamente a dos segundos, é evidente que sua multiplicação é um efeito consequente e necessário de nossa sensibilidade e da presença dos objetos; e portanto ele foi pouco judicioso ao supor que o coração do homem não pudesse ser preenchido senão por um objeto infinito ${ }^{272}$ ".

Ele combate em outra parte o argumento do engajamento $^{273}$ : "aquele que nadifica por assim dizer sua existência presente, na esperança de uma segunda existência que não terá jamais, risca e joga tudo o que ele é e o que ele tem contra nada".

Há, dizia Pascal, uma guerra intestina no homem entra a razão e as paixões ${ }^{274}$. - É uma loucura, responde Rémond le Grec, essa guerra natural que eles imaginaram entre a razão e as paixões; ela deve mais regulá-las que combatê-las, e trabalhar menos o propósito quimérico de desenraizá-las de nós mesmos do que temperá-las pelo gosto do espírito e pelo sentimento do coração ${ }^{275}$.

E seu irmão Rémond de Saint-Mard, quando Pascal reprova no homem a miséria de "não saber manter-se em repouso em um quarto ${ }^{276,}$, replica por sua vez:

É sempre um prazer ir: não se ama o repouso ${ }^{277}$.

O marquês de Lassay, no seu Recueil de différentes choses, se levanta contra a ideia absurda de explicar a natureza 
humana pela queda, e observa que o argumento do engajamento vale para todas as religiões tanto quanto para a cristã.

\footnotetext{
"Pascal pretende, diz o autor das Doutes sur les religions ${ }^{278}$, que os dois genealogistas (de Jesus Cristo) provam que os dois escritores não estavam de acordo $^{279}$ : isso é verdade, mas o Espírito Santo, que os inspirava todos os dois, devia estar de acordo com si mesmo".

"Eu creio com prazer, escrevia Pascal, nas histórias cujos testemunhos se fazem degolar ${ }^{280 \text {, }}$
}

A que o autor das Doutes replica:

"Os mártires não provam nada para uma religião. Cada religião tem devotos obstinados que sacrificam suas vidas pelo que eles olham como verdades essenciais à saúde ${ }^{281 "}$.

"Dir-se-á sem dúvida, faz observar Levesque de Burigny, que os progressos da religião cristã são acompanhados de circunstâncias que provam claramente que ela tem alguma coisa de sobrenatural. As nações abandonaram as religiões cômodas para então abraçar uma muito enganosa... Eis as declamações capazes de cegar gênios superficiais ${ }^{282 "}$.

Tenho muito medo que o mais notório desses gênios declamadores não seja Pascal, segundo quem a religião é contrária à natureza e "combate todos os nossos prazeres ${ }^{283}$,", e que tirara argumento dessa bizarrice para fazer admirar o seu estabelecimento.

O Traité des Miracles que dá o ms. 1194 da Mazarine ${ }^{284}$, toma Pascal a parte sem nomeá-lo, por ter feito da doutrina um meio de discernir entre os verdadeiros milagres e os falsos ${ }^{285}$.

Eu disse ${ }^{286}$ que talvez o $4^{\circ}$ caderno das Difficultés sur la religion fosse dirigido contra o intuito do abade Houtteville. Mas o oficial filósofo poderia muito bem visar Pascal, de quem Houtteville certamente tomara seu método.

Pascal, escreve com efeito Filleau de la Chaise ${ }^{287}$, reduzia a prova da religião a uma questão de crítica histórica. "Em vez de estar à mercê dessa pobre razão a quem é tão fácil de impor, eles somente têm que examinar para todas as provas, fatos e histórias: ou seja, coisas para as quais eles têm princípios infalíveis". Não é a essa maneira de argumentar que responde o intuito de apresentar "um sistema de religião fundado metafisicamente sobre as luzes naturais, e não sobre os fatos"? Pascal provara primeiro que a religião estava de acordo com a razão e com o sentimento, depois que ela era verdadeira da verdade de um fato. Seguindo uma ordem inversa, o oficial 
militar da marinha destrói, no seu $3^{\circ}$ caderno, os fatos da religião revelada, e estabelece, no último, o plano da crença puramente racional. Amparado por Malebranche ao qual ele se refere, e que seja, ou não, através de Houtteville, ele atinge Pascal.

O último capítulo do Examen critique de Burigny refuta "o argumento de que é preciso sempre tomar o partido mais seguro". É o famoso argumento do engajamento, já combatido por Boulainvilliers e Lassay.

Fazia também o objeto da dissertação lembrada por Victor Giraud, que aparece em 1743 nas Nouvelles libertés de penser, e no Recueil philosophique de Naigeon em 1770. Creuse bom, em uma coletânea manuscrita da Arsenal que citei ${ }^{288}$, de acrescentá-lo ali como suplemento o capítulo de Burigny ${ }^{289}$.

$\mathrm{Eu}$ não duvido que um estudo atento dos textos impressos ou manuscritos permita alongar bastante essa lista, e estabelecer que Voltaire, aqui como frequentemente, foi aquele que disse a alta voz o que, de muitos lados, cochichava-se ao ouvido. O Anti-Pascal se iniciava em vinte cérebros, após trinta anos; ele continuou a fermentar em muitos espíritos. Voltaire nadava em plena corrente. Ele foi aquele que realizou $o$ pensamento comum dos descrentes, e foi aquele que ousou publicar: do qual bem faltou-lhe cozinhar.

\section{A ORIGEM MAÇÔNICA DA "ENCYCLOPÉDIE"}

Quero tratar somente de mais um ponto, relativo às origens da Encyclopédie. É curioso notar, e não o percebemos muito nas nossas histórias da literatura ou da filosofia do século XVIII, que a Encyclopédie é uma empresa maçônica, ou ao menos que a sua ideia nasceu entre os franco-maçons.

Encontra-se em um volume intitulado Lettres de M. de Voltaire, avec plusieurs pièces de différents auteurs, La Haye, P. Poppy, MDCCXXXVIII, um "Discurso pronunciado à recepção dos Franco-Maçons, pelo senhor de Ramsay, grande orador da ordem".

O fragmento é conhecido há muito tempo pelos historiadores franco-maçons. Eles assinalam entretanto somente suas impressões posteriores; e eles não estão de acordo nem sobre seu autor nem sobre sua data. Em geral situam-na no ano 
de 1740; atribuem-na às vezes a Ramsay, mas sobretudo ao duque de Antin, grão-mestre a partir de 1740. A impressão de 1738 interdita a dupla hipótese de 1740 e do duque de Antin. Ela dá razão a Daruty que nas suas Recherches sur le rite Ecossais $(1879)^{290}$, reconhece esse discurso por ser aquele que Ramsy deveu pronunciar em 31 de março de 1737 e que lhe deu a ocasião de escrever ao Cardinal Fleury as duas cartas das quais Lemontey citou fragmentos ${ }^{291}$.

Eis aqui a passagem que nos interessa desse fragmento: Ramsay explica a obrigação para todo franco-maçom de "contribuir por sua proteção, por sua liberalidade ou seu trabalho, com uma vasta obra à qual nenhuma academia pode ser suficiente". E ele explica também a natureza dessa obra:

Todos os grão-mestres, na Alemanha, na Inglaterra, na Itália e por toda a Europa, exortem todos os sábios e todos os artistas da confraternidade a se unir para fornecer os materiais de um Dicionário universal de todas as artes liberais et de todas as ciências úteis, excetuadas somente a teologia e a política. Já se começou a obra em Londres, mas pela reunião de nossos confrades poder-se-á levá-la a sua perfeição em poucos anos. Ali se explicará não somente a palavra técnica e sua etimologia, mas dar-se-á ainda a história da ciência e da arte, seus grandes princípios e a maneira de nelas trabalhar. Dessa maneira a gente reunirá as luzes de todas as nações em uma única obra, que será como uma revista geral de tudo o que há de belo, de grande, de luminoso, de sólido e de útil em todas as ciências naturais e em todas as artes nobres. Essa obra aumentará, em cada século, segundo o aumento das luzes. É assim que se difundirá uma nobre emulação com o gosto das belas-letras e das belas-artes em toda a Europa ${ }^{292}$.

Eu não pude encontrar nenhum detalhe sobre a obra começada em Londres. Trata-se da Encyclopédie de Chambers? Ela fora publicada em 1728. E eu não vi em nenhuma parte que Chambers tenha sido reclamado pelos franco-maçons como um dos seus.

O que é certo é que de qualquer parte que a ideia tivesse vinda a Ramsay, ele a manteve.

Um preceptor do conde de Reuss, chamado Gensau, que travou em 1741, em Paris, conhecimento com Ramsay, e se entreteve frequentemente com ele, ouviu da sua boca muitos detalhes do mesmo gênero (sobre os franco-maçons), tais como o plano de uma subscrição a dez luíses por cabeça oferecida a todos os franco-maçons da Europa, estimados em 3.000, e cujo 
produto tenha sido primeiro empregado na impressão de um dicionário universal em francês, que devia compreender as quatro artes liberais bem como as ciências históricas. Ramsay ouviu ademais de Gensau que os franco-maçons de Paris tinham todo mês uma reunião onde se lia uma dissertação relativa a uma das quatro artes, e que era seguida de um jantar onde todos os grupos estavam misturados e onde cada um recebia somente uma medida fixa de vinho ${ }^{293}$.

Assim eis aqui, após o plano da obra, o meio de execução, a subscrição. Daguesseau acordou o privilégio da Encyclopédie cinco anos após a visita de Gensau a Paris, nove anos após o discurso de Ramsay, em 21 de janeiro de 1746. Há um liame entre esses fatos? Eu o ignoro. Entretanto se deve ressaltar um indício curioso: os dois livreiros que foram os promotores da empresa eram Briasson e Lebreton. A esse ponto Lebreton era franco-maçom, e mesmo dignitário da ordem ${ }^{294}$.

André-François Lebreton, impressor do Almanach royal desde 1725 em sociedade com a viúva Laurent d'Houry, e somente a partir de 1744, primeiro impressor do rei, foi o primeiro mestre da loja Louis d'Argent (1729); ele era ainda seu venerável inamovível em $1^{\circ}$ de janeiro de 1765 .

Foi por ele que a ideia maçônica foi levada a Daguesseau e a Diderot?

É evidente que, se pudesse-se fazer a demonstração, se essa grande máquina da Encyclopédie fosse uma obra maçônica, seria preciso atribuir à franco-maçonaria uma parte mais considerável que, por falta de documentos, até então não se pode lhe dar no movimento filosófico do século XVIII. Dever-se-ia estabelecer enfim a lista completa dos colaboradores que demandava Brunetière e que nós ainda não temos, e pesquisar quantos desses colaboradores pertenceram à maçonaria. A franco-maçonaria foi realmente no século XVIII alguma coisa de análoga - em senso inverso - ao que foi a companhia do Santo Sacramento no XVII?

Parece que os arquivos do Grande Oriente não guardam nada sobre o período anterior a 1775. Nos documentos publicados sobre a franco-maçonaria francesa, informo-me sobre as lojas, as recepções, os ritos, os graus, os locais, resumindo, sobre a história exterior da ordem; não encontro nada de preciso sobre seu espírito, nem sobre sua atividade, nem sobre sua influência. Os franco-maçons adotavam Sethos e as Considérations sur les Romains. Montesquieu era recebido em uma loja. Mas nem Terrasson nem Montesquieu deviam suas 
ideias à maçonaria. Qual era o trabalho das assembleias? O que se fazia ali? Não foi uma sociedade que difundiu mais do que criou as ideias filosóficas? A partir de que data pode-se assinalar um livro de inspiração, de origem claramente e certamente maçônicas?

\section{CONCLUSÕES}

Todas as observações que acabaram de ser lidas mais colocam questões do que as resolvem. Elas não terão sido inúteis, se elas derem às pessoas jovens a ideia de alguns dos trabalhos pelos quais pode estender-se e precisar-se nosso conhecimento ainda tão incompleto, e frequentemente mais sentimental que histórico, do século XVIII, e se elas lhes inspirarem a convicção de que há para um letrado mais a fazer do que carregar brilhantemente, como um hussardo, Voltaire, Diderot e Rousseau, ou de oferecer fantasias em sua honra: preparar com paciência e com consciência os meios de compreendê-los, de compreender o que realmente eles foram, o que realmente eles fizeram. A verdadeira grandeza e a verdadeira beleza deles nos aparecerão somente de modo confuso enquanto não tivermos uma visão clara da obra desses pequenos, desses esquecidos que os precederam, e do movimento dessa massa anônima da qual eles se criaram; somente então poderemos separar neles o que eles receberam do que eles criaram, e dizer exatamente onde eles eram somente aproveitadores ou intérpretes, onde eles acrescentaram o estilo charmoso e a paixão incendiária, onde enfim eles são inventores e mestres originais. Somente então nós os amaremos, ou nós os detestaremos, sabendo o porquê.

E somente então, também, nós veremos com uma visão distinta a vida francesa desabrochar e terminar nesses homens que a ultrapassam.

\section{NOTAS ADICIONAIS}

I. É preciso retificar a nota 145 , e modificar a hipótese feita nesse lugar sobre a data da redação do Militaire philosophe. Barcelona foi tomada pelos Franceses em 1697, 1706 e 1714, pelo arquiduque e pelos Ingleses em 1705. Pode-se então hesitar, para a composição da obra, entre as duas datas posteriores a 1701 onde os Franceses 
são ocupantes: ou seja entre 1706 e 1714. A data de Naigeon (18 de março de 1711) pode subsistir com a data de 1706: ela marcará a finalização da obra. Mas caso se admita que se trata da ocupação de 1714, será preciso corrigir 1711, e ler mais 1715 que 1714, porque Barcelona foi tomada somente em 11 de setembro de 1714.

II. Ascoli encontrou em um manuscrito da Biblioteca de Nantes (ms. fr. $35, p$. 157) detalhes sobre o cura Guillaume sobre o qual falei mais acima (p. 399-403). "Em um prefácio que ele colocou no início de sua obra, escreve o autor desconhecido da nota, ele diz que há muito tempo que se fala bastante do Livre des trois imposteurs, que não se encontra em nenhuma parte: seja que ele não tenha nunca existido na verdade ou que ele esteja perdido, é porque ele quer, para retomá-lo, escrever sobre o mesmo assunto...”. O manuscrito estava em "dois volumes in-fólios grossos e de uma bela escrita, e muito fina... Um outro manuscrito, e semelhante, foi encontrado depois da morte de um senhor". Após ter mencionado a captura e a penitência em uma abadia, a nota conclui: "Em 1733, ele recuperou inteiramente sua liberdade, e agregou-se uma pensão de 250 francos sobre a abadia de Saint-Liguaire a uma pensão que estava reservada sobre seu beneficio. Ele se chamava Guillaume, cura de Fresne-sur-Berny, irmão de um trabalhador de província: ele fora antes regente do colégio de Montaigu. Na sua juventude, ele fora arregimentado pelos Dragões, e em seguida, ele se fez capuchinho". Se essa biografia sucinta é exata, era um amável aventureiro esse Guillaume, uma figura que falta na Rôtisserie de la Reine Pédauque.

Notes

${ }^{1}$ A Revue des Cours publicou de 26 de dezembro de 1907 a 21 de abril de 1908 as notas de um estudante sobre os meus cursos de 1907-1908 e 19081909, que conduziam o grosso do assunto de 1680 a 1715.

${ }^{2}$ N. do T.: Segundo Frantz Funck-Brentano - Les lettres de cachet. Paris: Hachette, 1926 - este era um instrumento de suma importância para o funcionamento do regime monárquico tal qual existente na França do século XVIII. Ela expressava a vontade do rei, em um contexto cujo centro de gravidade da sociedade estava posto pela família. Brentano explica: "O Estado tinha o maior interesse no bom governo das famílias, na sua integridade, na manutenção das tradições segundo as quais cada uma delas se constituíra e que as sustentavam. O Estado não dispunha da imensa massa administrativa pela qual rege a sociedade moderna: com uma administração embrionária, ele governava por meio dos chefes de família que tornavam seu papel infinitamente mais cômodo espoliando-lhe de uma multidão de preocupações das quais ele se ocupa hoje" (p. 10). Paul Delsalle - La recherche historique en archives: XVIe-XVIIe-XVIIIe siècles. Paris: Ophrys, 2007 - define a "Lettre de cachet" da seguinte maneira: « Lettre de Cachet : carta fechada, autenticada pelo selo do soberano, e contendo uma ordem que deve ser executada sem publicidade, para proteger a segurança do Estado 
(grand cachet) ou a vida privada da família dos indivíduos envolvidos (petit cachet).»(p. 164). Essas duas citações nos permitem perceber como a "Lettre de cachet" é algo próprio do seu momento histórico, e traduzi-la de qualquer modo que seja seria diminuir muito o seu significado. Por essa razão, optei por deixar o termo francês no texto e explicar o seu significado em nota.

${ }^{3}$ Voltaire (Carta a Damilaville, 8 de fevereiro de 1762) diz oito. Mas em outro lugar (edição Moland, t. XXVI, p. 511), ele escreve dez.

${ }^{4}$ Ela era às vezes estranhamente aconselhada. Após uma batida feita em 16 de fevereiro de 1725 na casa de Le Prevost, livreiro-impressor em Rouen, o tenente de polícia deu os livros apreendidos para exame a Leullier, cura de São João do cardeal Lemoine. Este não encontrou nada a dizer à Abadia nem a Pascal; mas eis sobre o que ele se preocupou: "eu não vejo nada de passível de apreensão senão o Robinson, obra muita prejudicial para os costumes e a religião; as Aventures de Lazarille não valem muito mais; é um livro de lacaios" (Arch. de la Bast., t. XII, p. 515). Eu não me lembro se se devolveu ao pobre Le Prevost seus Robinson Crusoé e seus Lazarille de Tormès, nem se eles lhe valeram uma longa prisão.

${ }^{5}$ N. do T.: texto disponível em tradução brasileira: A VIDA e o espírito de Baruch de Espinosa: Tratado dos três impostores. São Paulo: Martins Fontes, 2007.

${ }^{6}$ Archives de la Bastille, t. XIII, p. 473-476.

7 Ibid., t. XIV, p. 221.

8 Ibid., p. 221-222.

9 Arch. De la Bast., t. XIV, p. 222.

${ }^{10}$ N. do T.: Segundo o Dictionnaire de la langue française de Émile Littré (1872-77), "Porcherons" seria um antigo bairro parisiense repleto de cabarés. Era formado pelo encontro das ruas do Faubourg-Montmartre e de SaintLazare.

${ }^{11}$ N. do T.: "vendedor ambulante" traduz o termo "colporteur". Esse era um elo importante da cadeia de produção e circulação de textos clandestinos em geral, geralmente formada por pelo menos três personagens diferentes: o autor, o editor e o vendedor. O estudo sobre o "colporteur" como parte integrante das discussões sobre os "delitos de opinião" na França do século XVIII foi apresentado nos diversos artigos que compõem o dossiê "Le délit d'opinion à l'âge classique: Du colporteur au philosophe", apresentado em La Lettre Clandestine, $\mathrm{n}^{\circ} 17,2009$.

${ }^{12}$ Ibid., t. XII, p. 220-221.

13 Ibid., t. XV, p. 338.

14 Ars., ms. 2091.

15 Houve também escritos políticos que circularam, como as Considérations do marquês de Argenson sur le gouvernement ancien et présent de la France, que não foram impressos senão em 1764. Voltaire os leu em 1739. J.J. Rousseau também as teve.

${ }^{16}$ A maior parte das obras sobre as quais falarei são já conhecidas. Mas elas foram vistas isoladamente, sem agrupá-las, sem observar o movimento que elas desenham. E elas foram vistas nos impressos incompletos e tardios. São os manuscritos, em seu estado original e em suas datas, que são interessantes.

17 Mazarine, ms. 1176. É também o título da edição de 1783. 
${ }^{18}$ B. Nat. ms. fr. 22925 , p. 6 (fim do sumário).

${ }_{19}$ Ms. fr. 20109 e 22926.

${ }^{20}$ Nota do ms. fr. 22926.

${ }^{21}$ Nota do ms. fr. 20109.

${ }^{22}$ Ms. fr. 9619, 9620. 17106, 20109, 22925, 22926.

${ }^{23}$ Ms. 2238 e 2560.

${ }^{24}$ Ms. 1176 e 1177. Esse último é intitulado: Nouveau système de religion chrétienne ou le Ciel ouvert à tous les hommes.

${ }_{25}$ Bull. De la Soc. Des Arch. Hist. De la Saintonge, t. XII, p. 49.

${ }^{26}$ Ms. 201 e 202.

${ }^{27}$ N. do T.: Segundo o Dictionnaire de l'Académie française, $6^{\text {ème }}$ éd. (1835), "récollets" era o nome que recebia o grupo de religiosos reformados da ordem de São Francisco. O nome era devido à exigência do espírito de meditação e recolhimento que fazia aos seus membros.

${ }^{28} \mathrm{O}$ abade Léon de Beaumont, que foi amigo de Fénelon, foi nomeado bispo em fevereiro de 1716, mas sagrado somente em 3 de julho de 1718 (Gallia Christiana, t. II, p. 1088).

${ }^{29}$ Mazarine, ms. 1176.

30 Bulletin de la Soc. Des Arch. Hist. De la Saintonge, t. XI, p. 387 (Carta do Monsenhor de Champflour); t. XII, p. 49 e 218. - Eu não pude ver a brochura de Louis Audiat, Un oublié saintongeais, Pierre Cuppé. Sauveterre, 1881, in8,9 pages.

${ }_{31}$ Bengesco, Bibliographie de Voltaire, II, 381. - eu possuo uma edição in-8, s.l.n.d. com 51 p., tendo às p. 5 e 6 a apresentação: Não é então a primeira edição. - Encontrar-se-á em Bengesco uma bibliografia sumária, mas suficiente de Meslier.

${ }^{32} 3$ vol. in-8. - A biografia dada por Rudolf Charles não tem nada de original: ela é feita sobretudo segundo Boulliot. Rudolf Charles recolheu no fim de seu Prefácio todas as passagens de Voltaire onde se trata de Meslier.

${ }^{33}$ Voltaire, Oeuvres, ed. Moland, t. XXVI, p. 511.

${ }^{34}$ Cf. acima, n. 1.

${ }^{35}$ Voltaire a Damilaville, 8 de fevereiro de 1762.

${ }^{36}$ Prefácio, p. XLIV.

${ }^{37}$ Ms. fr. 19458-19460. Os três manuscritos contêm as duas cartas de Jean Meslier aos curas de suas redondezas. Os mss. 19458 e 19460 têm um Quadro das principais matérias do conteúdo.

${ }^{38}$ Ms. 2237 e 2559.

${ }^{39}$ Ms. 17 e 18.

${ }^{40}$ Ms. 2558.

${ }^{41}$ Ms. 1572 e 1573 , este datado.

${ }^{42}$ Ms. 12 (1).

${ }^{43}$ N. do T.: Coletânea de textos clandestinos cuja responsabilidade é atribuída a Voltaire. Publicada sem indicação de lugar, autor ou editor.

${ }^{44}$ N. do T.: Londres, 1768. 2 v. Petit $8^{\circ}$ (Cf. BARBIER, A.A. Dictionnaire des ouvrages anonimes. 3ème éd. aug. rev. Paris: Paul Daffis, 1879. T. IV, p. 62. As demais menções a Barbier colocadas em nota serão sempre a remeter a esta obra, segundo os seus diversos volumes). É uma coletânea geralmente atribuída a Voltaire, ainda que Barbier vacile frente a essa atribuição.

${ }^{45}$ T. II, p. 383. 
${ }^{46}$ N. do T.: Segundo o Dictionnaire de la langue française de Émile Littré (1872-77), "Cristícola" se referia ao modo como os adversários dos cristãos se referiam a eles. Significava "adorador do cristo", e fica claro pela definição que se tratava de algo pejorativo.

47 Ed. Moland, t. XXIV, p. 294.

${ }^{48} \mathrm{Eu}$ não sei onde ela apareceu pela primeira vez. R. C. d'Ablaing van Giessenburg a resume.

49 Moreri, que dá o texto de Voltaire (no rodapé da p. 294 da edição Moland), é substituído no ms. por Comines, que o Testament com efeito cita mais de uma vez. - O senhor de Touilly é chamado Trouilly no manuscrito. Boulliot o chama de Senhor de Clairy.

${ }^{50}$ N. do T.: refere-se a Jacques-André Naigeon. Conhecido sobretudo como filósofo, a obra talvez mais famosa e influente de Naigeon tenha sido a sua Encyclopédie Méthodique, editada em Paris por Panckoucke e citada diversas vezes por Lanson no presente artigo. Ele era grande admirador de Diderot e amigo de d'Holbach, ajudando-lhe inclusive na publicação do seu Système de la Nature. Para maior detalhamento, Cf. o verbete NAIGEON (Jacques André) no DICTIONNAIRE des lettres françaises: le XVIIIe siècle. Paris: Fayard, 1995, p. 960.

51 Encyclopédie méthodique, Philosophie, t. I, p. 239.

${ }^{52}$ Ars., ms. 2558, Apresentação do extrato. O texto é aqui quase aquele da Apresentação in extenso.

${ }^{53}$ A Biblioteca do Arsenal possui um exemplar da obra de Fénelon com as notas de Meslier. Fez-se-lhe cópias que circularam. Cf. Prefácio de R. C. d'Ablaing de Giessenburg, p. XXXIX. - Tinha-se ainda de Meslier alguns sermões manuscritos semeados de audácias (Boulliot, Biographie ardennaise, t. II, p. 206 et seq.).

${ }^{54} \mathrm{~N}$. do T.: A recorrência à figura dos três impostores era algo comum e recorrente na discussão filosófica apresentada nos manuscritos clandestinos. Ela pretende que Jesus, Moisés e Maomé - ou seja, os fundadores das três maiores religiões do mundo - não passavam de impostores, que utilizavam a religião em benefício próprio e geralmente com fins políticos. Essa é a leitura que se pretende apresentar em um dos textos clandestinos mais famosos e mais difundidos, o Tratado dos três impostores, que também circulou sob o título $A$ vida e o espírito do senhor Baruch de Espinosa. Cf. nota 5.

55 Oeuvres, ed. Moland, t. XXVI, p. 511.

56 O Militaire philosophe (no seu verdadeiro texto) igualmente: Cf. mais adiante, p. 403-407.

${ }^{57}$ N. do T: "Descanse em paz".

${ }^{58}$ Ms. 2237.

${ }^{59}$ p. $980-982$.

60 N. do T.: Refere-se certamente a Valerius Publicola, um dos fundadores da república romana. Segundo Pierre Larousse - no seu Grand dictionnaire universel: Français, historique, géographique, biographique, mythologique, bibliographique, littéraire, artistique, scientifique, etc. Paris, [s.d.], tome XV, p. 741 - dentre algumas de suas medidas, ele fez uma lei segundo a qual se permitia matar, sem nenhuma formalidade jurídica, todo homem que aspirasse à tirania. E medidas como essa renderam-lhe o epíteto de publicola, ou seja, popular. É exatamente esse radicalismo que o texto de Meslier 
pretende evocar, e é também por tal radicalismo que este mesmo autor é conhecido.

61 Ms. 2237, p. 956-958.

62 p. 959.

63 "Ces prétendus saints et divins livres", p. 966.

${ }^{64}$ p. 966-967.

${ }^{65}$ N. do T.: Émile Littré - Dictionnaire de la langue française, 1872-77 define a Carmagnole da seguinte maneira: "Canção de ar vivo [tocada] a 6/8, e dança que o partido revolucionário gostava em 93. Era como uma roda que se dançava sobre os lugares e em jardins públicos, com um extremo entretenimento". No texto é utilizada como "dançar a vitória".

${ }^{66}$ O padre Castel e o abade Pluche representariam a curiosidade científica na ortodoxia.

${ }^{67}$ Leremos sobre ele com proveito a excelente introdução feita por Colonna d'Istria a uma tradução inédita da Ética de Spinoza, que ele crê poder atribuir a Boulainvilliers (Paris, 1907, in-8).

${ }^{68} \mathrm{Eu}$ indiquei o espírito do livro em uma lição da Sorbonne cuja substância foi reproduzida na Revue des Cours de 16 de abril de 1908.

${ }^{69}$ Ms. fr. 9111 e $12242-12243$.

70 Ms. 2235 e 2236.

71 Ms. 3558 e $3560^{2}$. - O texto de $3560^{2}$ parece resumido e incompleto. Ele é seguido de uma crítica em forma de carta sobre os efeitos do sistema. A Vie falta.

${ }^{72}$ Assim no ms. B. N. fr. 12242.

${ }^{73}$ Ms. 1198, Dissertation sur l'Écriture sainte et les prophéties, par M. de Boulainvilliers.

${ }^{74}$ N. do T.: O texto original diz "Barbin". No entanto, acredito tratar-se de um erro de digitação. Pelo contexto e pelo teor da discussão, fica claro que se trata de Barbier.

75 Ms. 15-16, t. I.

76 Ms. fr. 9107.

${ }^{77}$ Uma nota (p. 133) onde se trata da mina de Noyers em Touraine, pode servir para encontrar o autor, ou melhor um dos possuidores do manuscrito?

78 É preciso não confundir essa obra espinosista redigida em francês com o tratado latino e deísta De Tribus impostoribus, falsamente datado de 1598 e impresso somente por volta de 1753 (Cf. A notícia de Philomneste Junior, ou seja G. Brunet, na edição dada por J. Gay em 1861).

${ }^{79}$ B. N. ms. fr. 12243; Ars., ms. 2236.

${ }^{80}$ Ms. 1193. Encontra-se nesse manuscrito um Aviso ao leitor em latim e uma carta latina de Frédéric II a Othon da Baviera (com tradução das duas peças), uma nota onde o autor diz ter recebido do abade Nicaise no ano passado 1693 uma dissertação de La Monnoye relativa ao tratado, uma dissertação que é a Carta afirmando a existência da obra em resposta a La Monnoye, e enfim o Tratado que, em treze capítulos, dá a mesma matéria que as outras cópias. A nota bem poderia originalmente provir de Boulainvilliers. A dissertação é aquela que foi impressa em 1716: ela é posterior a 1706.

81 Ms. 24-25.

${ }^{82}$ Ms. 200.

${ }^{83}$ Lição resumida na Revue des Cours de 23 de dezembro de 1909. 
${ }^{84}$ Há oito capítulos no Esprit de Spinosa, nove nos manuscritos, seis no De Tribus Impostoribus. O segundo capítulo do Esprit é repartido sob dois títulos nos manuscritos. O capítulo terceiro do De Tribus Impostoribus corresponde a três capítulos do Esprit e de nossos manuscritos. A cópia da Mazarine dá os Trois Imposteurs em treze capítulos.

${ }^{85}$ Falo dos n. 12242-3 da B. N. e 2236 da Arsenal. No ms. 2235 da Arsenal falta o Esprit de Spinosa.

${ }_{87}^{86}$ Dictionnaire historique, 1758, ART. De Tribus impostoribus, t. I, p. 223 n. 87 Ibid., p. 324.

${ }^{88}$ Prosper Marchand morreu em 1756. O autor da dissertação em resposta a La Monnoye afirma tê-la visto e traduzido em Frankfurt em 1706. (Cf. Maz. ms. $1193^{2}$ e Pr. Marchand, Dict. Hist., t. I, p. 322).

${ }^{89}$ Ars., ms. 2236.

90 Dict. hist., t. I, p. 325.

91 Essa nota não está assinada. Não tenho outro fundamento para atribuí-la a Boulainvilliers senão sua curiosidade por obras semelhantes. E é pouco. Eu não proporia hipótese, se a discussão de explicações aventurosas não fosse útil para provocar as pesquisas de onde geralmente a verdade sai. - Lê-se no título da obra no mesmo ms.: "Por Mercier de Compiègne. Essa obra foi impressa em 1796, in-8, sob a falsa data Philadelphie". Confusão grosseira de um possuidor tardio do ms.: Mercier de Compiègne foi somente o editor do escrito em 1796.

92 B.N. fr., 12242-12243; Ars., 2236.

93 Ars., 2236.

94 O marquês de Mirabeau certamente utilizou a vida manuscrita de Plelo pelo cavaleiro da Vieuville da qual se serviu Rathery na sua obra: Le chevalier de Plelo, un gentilhomme français au XVIIle siècle, 1876, in-8. Mas Rathery não conheceu o escrito do marquês. A passagem que eu cito não tem sua fonte na Vieuville; também o fato que é contado ali escapou a Rathery. No ms. autógrafo, a passagem cobre as largas margens das páginas 56-61; é uma adição que provém de informações recolhidas após o acabamento ou durante a primeira redação.

95 Arch. Nat., M 356, doss. IV, Brehan ${ }^{1}$ : Vie de Louis-Robert-Hippolyte de Brehan, comte de Plelo. - É o manuscrito autógrafo. Existe nos arquivos duas cópias dessa vida: M 356, doss. IV, Brehan ${ }^{2}$, e M $783^{11}$. Chamarei esses três manuscritos A $\left(=356^{1}\right), \mathrm{B}\left(=356^{2}\right), \mathrm{C}\left(=783^{11}\right)$. B foi copiado de A; e C parece derivado de $\mathrm{B}$.

${ }_{96}$ BC abreviava [J.-C].

${ }^{97} \mathrm{C}$ omite ali.

${ }^{98}$ Reconhece-se aqui a palavra do dom Juan de Molière, e pode-se então assegurar que essa formula é menos uma expressão de fé racional no métodos das matemáticas, que uma declaração particular da absurdidade do dogma da Trindade.

${ }^{99}$ A mas riscado e substituido por $\mathrm{e}$.

${ }^{100} \mathrm{~A}$ bem digerido e no todo palavras riscadas.

${ }^{101} \mathrm{BC}$ omitem a passagem Ele mostrava [...] muito antiga.

${ }^{102}$ A coloca riscado.

${ }^{103} \mathrm{C}$ esse.

${ }^{104} \mathrm{C}$ e [teve]. 
${ }^{105}$ B C, concílio.

${ }^{106} \mathrm{~A}$ e [eu] riscados.

${ }^{107}$ N. do T.: Paul Hazard - La crise de la conscience européenne. Paris: Fayard. 1995, p. 161 et seq. - cita o caso de Jacques Aymar como um famoso exemplo de utilizador da varinha divinatória e que seria capaz de indicar ladrões e meliantes com a aproximação da sua varinha. Ele cita também a utilização comum de tal expediente por diversos outros personagens em lugares espalhados pelo mundo para a localização de água ou ouro, para colocar no lugar ossos deslocados, estancar hemorragias... O importante é perceber que são casos sempre tratados como impostura, que é certamente o mesmo sentido que se pretende dar à história de Moisés no trecho citado. O texto analisado representa bem alguns dos elementos da crise da consciência europeia, tal qual descrita por Hazard.

${ }^{108}$ A o fluxo e riscado.

${ }^{109}$ A que riscado.

${ }^{110}$ A escreve segonde. [N. do T.: em francês a palavra seria seconde, e o autor observa que está escrito em A segonde].

${ }^{111} \mathrm{BC}$ omitem a página eu duvido [...] pelos homens.

${ }^{112} \mathrm{BC}$ Nosso cura.

${ }^{113} \mathrm{BC}$ uma [gente]

${ }_{114}^{114} \mathrm{AB}$ escrevem Moncrist. - C, Mongrift.

${ }^{115}$ A o número e riscado.

${ }^{116} \mathrm{~B}$ tem as palavras também - hipócrita, mas elas estão riscadas; $\mathrm{C}$ as omite.

${ }^{117} \mathrm{BC}$ omitem de. [N. do T.: refere-se à frase em francês: "[...] il n'entendait pas de raillerie là-dessus"].

${ }_{118}^{18} \mathrm{BC}$ sobre esse artigo.

${ }^{119}$ A esse livro com riscados.

${ }^{120}$ A eu riscado. [N. do T.: trata-se do particípio passado do verbo avoir, que fora empregado em um tempo composto no manuscrito $\mathrm{A}$ ].

${ }^{121} \mathrm{~A}$ entre as mãos riscados.

${ }^{122} \mathrm{BC}$ a [isso].

${ }^{123} \mathrm{~A}$ escreve o $\mathrm{C}$.

${ }^{124} \mathrm{~A}$ n'en [en riscado]. [N. do T.: refere-se à utilização do pronome francês en na frase: "[...] et lui dit de n'en point parler de ce qu'il lui avait dit", conforme a encontra no manuscrito A].

${ }^{125}$ Esse nome está riscado e tornado ilegivel em A.

${ }^{126}$ A ter [a riscado]. [N. do T: trata-se do verbo avoir (ter), que ao ter a letra $a$ riscada torna-se voir (ver)].

${ }^{127} \mathrm{BC}$ lá ele diz a missa (C traz o texto de A riscado e substituído por a variante).

${ }^{128} \mathrm{C}$ omite e.

${ }^{129} \mathrm{BC}$ em.

${ }^{130} \mathrm{~A}$ e [ele].

${ }^{131} \mathrm{BC}$ omitem e.

${ }^{132}$ Funck Brentano, Les Lettres de cachet à Paris, 1903, p. 232, $\mathrm{n}^{\text {os }} 3037 \mathrm{e}$ 3038 (B.A. 12476-12479 e 12551). - Fr. Ravaisson, Archives de la Bastille, t. XIV, p. 197-201.

${ }^{133}$ Archives de la B., t. XIV, p. 200.

Problemata: R. Intern. Fil. Vol. 04. No. 03. (2013), p. 382-441

ISSN 2236-8612 
${ }^{134}$ Dict. hist., t. I, p. 325. ARTIGO Impostoribus (De Tribus), nota R.

${ }^{135}$ Maz. ms. 1195 (1 e 3).

${ }^{136}$ Maz. ms. 1189.

${ }^{137}$ Maz. ms. $1195^{3}$.

${ }^{138}$ Les opinions des anciens sur les Juifs. Ver mais adiante, na próxima [parte desse] artigo.

${ }^{139}$ Ms. 1163.

${ }^{140}$ Ms. 1197, intitulado: Sisteme de religion purement naturelle et objections contre le christianisme adressées au P. Malebranche par M. militaire dans la marine. - O ms. 1192 (2) parece ser idêntico ao 1197.

${ }^{141}$ Ms. 1163, Prefácio.

${ }^{142}$ Ms. 1197, título, e p. 74. - Entendo por oficial militar, não um marinheiro, mas um oficial de um dos regimentos da marinha.

${ }^{143}$ Ms. 1163, Prefácio.

${ }^{144}$ Ms. 1197 , p. 36.

${ }^{145}$ Barcelona foi ocupada pelos franceses em 1697 e 1714, e pelos ingleses em 1706. A expressão: "meu filho que está diante de Barcelona" prova que não é preciso pensar senão nas ocupações de 1697 ou 1714. É preciso se deter na data de 1714, porque a obra fala (p. 60 do ms. 1163) de uma tumba de santo em Amiens onde afluíam as oferendas, e que foi encontrada vazia em 1701. Naigeon coloca ao fim do Militar filósofo a data seguinte: A L........., em 18 de março de 1711. L deve ser Lorient, se o autor é um oficial da marinha. Quanto à data 1711, Naigeon pode ter lido mal um $4 \mathrm{em}$ um ms., ou pode ter corrigido mal as provas do livro.

${ }^{146}$ Mil. phil., p. 19; ms. 1163, p. 7.

${ }^{147}$ Mil. phil., p. 20; ms. 1163, p. 7.

${ }^{148}$ Ms. 1163, carta servindo de Introdução.

${ }^{149}$ Ms. 1163, p. 9; Mil. phil., p. 21.

${ }^{150}$ Mil. phil., p. 21, nota.

${ }^{151}$ Ms. 1163, p. 80; Mil. phil., p. 114.

${ }_{153}^{152}$ Naigeon suprime Lucrécio e acrescenta Hobbes (Mil. phil., p. 4).

${ }^{153}$ Alusões ao milagre de Madame Lafosse, 1727, e do diácono Pâris, 172832 (p. 147). Se essas alusões estão no ms. 1163, onde eu não soube encontrálas, isso confirmaria a hipótese de que a obra não é de uma única mão nem de uma única época.

${ }^{154}$ Essas duas partes, no ms. 1163, estão reunidas por uma paginação seguida. Cada uma das duas outras é paginada a parte.

${ }^{155} \mathrm{O}$ ms. 1197 é dividido em 2 partes, das quais uma é tirada do $1^{\circ}$ caderno, a outra do $4^{\circ}$, com empréstimos do caderno precedente.

${ }^{156}$ Ms. $1163,4^{\circ}$ caderno, p. $150-151$.

${ }^{157} \mathrm{E}$ o último capítulo desse tratado é justamente sobre os demônios e os espíritos.

${ }_{158} 3^{\mathrm{a}}$ parte, p. 19.

159 "Ninguém crê no milagre pintado no quadro que a mais espiritual e a mais sábia cidade do mundo ofereceu na igreja Sainte-Geneviève para o pretenso apoio que santa Geneviève deu à França no ano passado 1709" (3 $3^{\mathrm{a}}$ parte, $\mathrm{p}$. $103)$.

${ }^{160}$ Na próxima [parte deste] artigo.

${ }^{161}$ Ms. 1163, p. 101: $16^{a}$ verdade, omitida no Mil. phil. 
${ }^{162}$ Ms. 1163, p. 126.

${ }^{163}$ Ms. $1163,4^{\circ}$ caderno, p. 32; ms. 1197, p. 230.

${ }^{164}$ Carta servindo de Introdução.

${ }^{165}$ P. 3.

${ }^{166}$ P. 11.

${ }^{167}$ P. 15 .

${ }^{168}$ Mil. phil., p. 16.

${ }^{169}$ Ms. 1163, p. 4.

${ }^{170}$ Mil. phil., p. 71.

${ }_{172}^{172}$ Ms. 1163, p. 58.

${ }_{173}^{172}$ C. mais adiante à p. 405.

${ }^{173}$ O ms. 1192 da Mazarine sobre o qual vou falar leva a menção Século dezoito na parte de baixo da folha do título. Disso se conclui imediatamente que a cópia foi feita no século XIX.

${ }_{174}$ Mss. $1192^{3}, 1193^{1}, 1199^{2}, 3564^{1}$.

${ }^{175}$ Mss. fr. $13213^{2}, 13214,13215$.

${ }^{176}$ Ms. $2091^{3}$.

${ }^{177}$ Ms. $1574^{2}$.

${ }_{179}^{178}$ Mss. 13 e 14.

${ }^{179}$ Ms. 183.

${ }^{180}$ Veja p. 397 - O mesmo ms. reúne às vezes os dois exames. Assim, Maz. ms. 1199: (1) Examen de la religion en 14 chapitres; (2) Examen de la religion en 15 chapitres (é deste que me ocupo nesse momento).

${ }_{181}^{182}$ Maz. 1192, cap. XI - Ed. de 1767, cap. X, p. 33.

${ }^{182}$ Aqueles que encontramos à pag. 38 da ed. 1767.

${ }^{183}$ Essa Advertência é composta das notas de dois autores ao menos, um escrivão em 1741, e outro após 1750.

${ }^{184}$ Uma confusão do autor do Catálogo dos mss. da Mazarine introduz aqui diversos nomes que não the dizem respeito. Esse autor escreve: "Atribui-se falsamente essa peça, diz uma nota do ms., a Boindin e a Voltaire: ela é de Petit, Queimada na Place de Grève por suas estrofes contra a Virgem". Mas essa nota não tem relação com a nossa obra. Ela tem relação com um poema intitulado: Doutes sur les erreurs et l'inutilité des cultes, que está inserido entre a Advertência e o capítulo 1 das Doutes sur la religion.

${ }_{185}$ B. N. 13214; Rouen, 1574.

${ }^{186} \mathrm{O}$ teólogo moderado que colaborou com a Enciclopédia.

${ }_{188}^{187}$ Maz., 1192; Fécamp, 14.

${ }^{188}$ Impressão de 1761.

${ }^{189}$ Trata-se da Bibliothèque raisonnée des ouvrages des savans de l'Europe, que é impressa na França entre os meses de junho de 1738 e julho de 1753. Segundo as indicações do Dictionnaire des journaux 1600-1789 - dirigido por Jean Sgard, Paris, Universitas, 1991 e disponível no site $<$ http://c18.net/dp/dp.php?no=169> - trata-se de um periódico pouco estudado e sobre o qual é difícil dar muitos detalhes. Mesmo os seus colaboradores restaram anônimos por muito tempo, não obstante o referido Dictionnaire consiga nos indicar muitos nomes nesse sentido.

${ }^{190}$ Ms. 1193 da Mazarine, cap. IX: Da ideia que nós devemos ter de Deus... Cap. XI: Que há um ser supremo.

${ }^{191}$ Ars., 2091, cap. XIV. Maz., 1193, cap. X. 
${ }^{192}$ N. do T: Ensina-me o caminho que devo seguir.

${ }^{193}$ B. N., mss. fr. 13215 e (salvo algumas variantes sem importância) 1321313214.

${ }^{194}$ Le Poême de Pope, etc., p. 1.

${ }^{195}$ Quérard assinala uma edição gr. In-8 de 1766 dessa obra.

${ }^{196}$ Les Supercheries littéraires dévoilées, art. FRÉRET.

${ }^{197}$ Nas ideias filosóficas que o dogma exprime.

${ }^{198}$ Hist. de l'Acad. des Inscr., t. XXVII, p. 88.

${ }^{199}$ Étude historique sur Jean Lévesque de Burigny, Travaux de l'Acad. De Reims, t. 66, p. 218.

${ }^{200}$ Ibid.

${ }^{201}$ Ed. 1767 , p. 88 .

${ }^{202}$ p. 103.

$2031728-1732$

${ }^{204}$ p. 149.

${ }^{205}$ Ms. fr. 13212.

${ }^{206}$ Ms. 1198, Recueil de pièces.

${ }^{207}$ Ms. 2125.

${ }^{208}$ Mss. $184^{1}$ e 185.

${ }^{209}$ Ms. 1198.

${ }^{210}$ Ms. $2557^{1}$.

${ }^{211}$ Ms. $184^{2}$.

${ }^{212}$ Ms. $2557^{6}$.

${ }^{213}$ Esse deve ser o escrito impresso em 1743 nas Nouvelles libertés de Penser e em 1770 por Naigeon no Recueil Philosophique. Ele foi escrito depois de 1700: porque se lê (p. 29): "Van Helmont, filósofo do último século".

${ }^{214}$ Cf. Lettres philosophiques de Voltaire, éd. critique, par G. Lanson, t. I, p. 190.

${ }^{215}$ Magasin encyclopédique, $2^{\circ}$ année, 1796, t. V, p. 234.

${ }^{216}$ Oeuvres, 1820, in-8, t. I, p. CII.

${ }^{217}$ Em 1739

${ }^{218}$ Loc. Cit., p. 486.

${ }^{219} 17$ de julho de 1766. Lettres à Voltaire, publiées par F. Caussy, Rev. D'Hist. Litt., janv.-mars, 1909.

${ }^{220}$ Ms. fr. 15288 .

${ }^{221}$ Ms. $1193^{4}$.

222 Ms. 5805.

${ }^{223}$ Duthilleul, Manuscrits de la Bibliothèque de Douai, 1846, $\mathrm{n}^{\circ} 668$.

${ }^{224}$ Mss. 1569-1570, t. II.

${ }^{225}$ Devia existir além disso ao menos o exemplar de Duclos.

${ }^{226}$ Loc. Cit., p. 482.

${ }^{227}$ Mss. $3564^{2}$ e 1196.

${ }^{228}$ Eu o conjecturo pela menção Século dezoito na parte de baixo da página de título.

${ }^{229}$ Mss. 1569-1570, t. II, 1571 e 1572.

${ }^{230}$ Mss. 15-16.

${ }^{231}$ Mss. 15-16, t. II.

232 T. III, p. 513.

${ }^{233}$ p. 330 . 
${ }^{234}$ 1727-1728; ou algum abreviado como o do ms. fr. 13224 da Nacional.

${ }^{235}$ Ms. 1196, p. 8.

${ }^{236} \mathrm{O}$ ms. 1571 de Rouen também contém notas.

${ }^{237} \mathrm{O}$ texto de La foi anéantie está em melhor ordem, mais claramente disposto, e às vezes desenvolvido. Um sexto fato é adicionado (Nombre des Israélites revenant de la Captivité de Babylone). Depois vem uma outra obra La Foi détruite et examen des principaux faits contenus dans le Nouveau Testament, traduit du latin de Hobbes, 1763, com um Discurso preliminar, onde a disposição da argumentação e do texto do precedente escrito se reencontra, mas que não é necessariamente da mesma mão. A data de 1763 pode se aplicar ou a esse arranjo e extensão do texto primitivo, ou ao estabelecimento da cópia.

${ }^{238}$ p. 16.

${ }^{239}$ N. do T: "folha de guarda" é um elemento próprio da apresentação material do livro e se refere à página - geralmente branca - que se coloca entre a capa do livro e a sua folha de rosto. Ela não faz parte necessariamente do conjunto de elementos a serem analisados em um estudo de bibliografia material, por ser algo acrescentado pelo encadernador no momento da encadernação.

${ }^{240}$ Cf. p. 405 .

${ }^{241}$ Ms. fr. 13213.

${ }^{242}$ Ars., 2091, fol. 1-103; B. N., fr. $13213^{1}$, p. 1-121.

${ }^{243}$ Ars., 2091, fol. 104-235.

${ }^{244}$ Cf. mais acima p. 403.

${ }^{245}$ Ms. 1575.

${ }^{246}$ O ms. 1194 da Mazarine contém uma Dissertation et preuves de l'éternité du monde, que não tem relação com o texto do Monde de Mirabaud (nova edição, Londres, 1778).

${ }^{247} \mathrm{O}$ texto impresso (tal qual o dá a nova edição de Londres, 1778) acrescenta alguns trechos ao início e ao fim dos capítulos da redação das três cópias manuscritas de Paris, que não oferecem, parece, diferenças consideráveis entre elas. Em vez da conclusão impressa, elas se terminam todas as três pelos versos seguintes:

A morte é a última linha das coisas [N. do T.: frase em latim no original]

Amável e cara Iris, a quem rendo homenagem

Dessa pequena obra,

Quando a Parca inflexível tiver cortado teus dias,

Amando-a tanto que te adoro

Deve sobreviver a seu curso.

Tu poderás no seu coração algum tempo viver ainda,

Mas não te prometes absolutamente, lendo esse tratado,

Qualquer outra imortalidade.

${ }^{248}$ Cf. mais acima, p. 398.

${ }^{249}$ Maz., ms. $1195^{4}$.

${ }^{250}$ Maz., mss. 1194 e 1195.

${ }^{251}$ Cf. mais acima, na p. 388.

${ }^{252}$ Maz., ms. $1195^{2}$.

Problemata: R. Intern. Fil. Vol. 04. No. 03. (2013), p. 382-441

ISSN 2236-8612 
${ }^{253}$ Maz., 3563.

${ }^{254}$ B. N., ms. fr. 13224

${ }^{255}$ Rouen, ms. 1580.

${ }^{256}$ Impr. em 1689.

${ }^{257}$ Título análogo àquele do último capítulo das Doutes sur la religion, no ms. da Mazarine 1193 e as cópias similares: "Chap. XI. Qu'il y a un être suprême; et la conduite qu'un honnête homme doit garder dans la vie".

${ }^{258}$ Bayle, Dict. Crit., art. KNUTZEN.

${ }^{259}$ p. 128.

${ }^{260} \mathrm{O}$ adjetivo nouvelles [novas] faz talvez alusão ao escrito redigido em 1741 sobre o qual falei mais acima (p. 386). O mesmo vendedor ambulante, o Petit Guillaume, vendia as duas obras. É ele, escreve o isento Perrault, em 16 de janeiro de 1743, que "distribui e dá a vender aos outros vendedores ambulantes as Nouvelles libertés de Penser". Ele as recebia de um chamado Constantin. Prendeu-se todos os dois, com a servente de Guillaume que comeu o fragmento (Arch. de la Bastille, t. XII, p. 231).

${ }^{261}$ Será preciso estar atento que às vezes pode ser Voltaire que caminha à frente [do seu tempo]. Eu vi no escrito de Mirabaud: Opinions des anciens sur la nature de l'âme, alguns turnos e argumentos que poderiam vir da XIII ${ }^{\mathrm{a}}$ carta inglesa ( $1^{\text {a }}$ ou $2^{\mathrm{a}}$ redação).

${ }^{262}$ Bouillier, Janet, Delbos, Colonna d'Istria, etc.

$263 \mathrm{Eu}$ dei algumas indicações que enriqueci aqui, mas ainda insuficientemente, nas lições que foram reunidas na Revue des Cours et Conférences, de 2 de abril de 1908, e de 2 e 23 de dezembro de 1909.

${ }^{264}$ Mémoires, p. XCVIII, no t. I das Euvres, 1820, in 8.

${ }^{265}$ Saint-Évremont, Euvres, ed. In-12, 1706, t. V, p. 364-365. - Cf. ed. 1726, t. V, p. 274-275 e as notas de Desmaizeaux.

${ }^{266}$ Ibid., ed. 1706, t. V, p. 355.

${ }^{267}$ Euvres, t. IV, p. 525, n. 1, e 876, n. 5.

${ }^{268}$ N. do T.: Trata-se certamente de Camille Falconet, médico e filho de Nöel Falconet. Sua importância está no fato de ter sido um grande colecionador de livros. Sua biblioteca contava com aproximadamente 50.000 volumes. Segundo o DICTIONNAIRE des lettres françaises: le XVIIIe siècle. Paris: Fayard, 1995, ele teria doado à Biblioteque Royale francesa em 1742 cerca de 11.000 livros que esta não possuia.

${ }^{269}$ V. Giraud o suspeitou sem ver-lhe toda a sua força, no seu Pascal, 3. ed., p. 227.

${ }^{270}$ Euvres, 1706, in-12, t. I, p. 145. Eu não pude saber a data nem a coletânea onde esse fragmento fora publicado: valeria a pena buscá-lo.

${ }^{271}$ Réfutation des erreurs de Spinoza, 1731, p. 191-192.

272 ... Esse abismo infinito (o desejo do homem) só pode ser preenchido por um objeto infinito e imutável (Pensées, ed. de 1687, cap. III, p. 37).

${ }^{273}$ Réfutation, p. 160.

${ }^{274}$ Pensées, ed. de Port-Royal, 1687, cap. IX, p. 75. - Ed. Brunschvig, in-16, $\mathrm{n}^{\circ} 412$.

275 Agathon ou De la Volupté, no Recueil de divers écrits, publ. por SaintHyacinthe, 1736, p. 41.

${ }^{276}$ Ed. 1687, cap. XXXVI, p. 203. - Ed. Brunschvig, n 139.

${ }^{277}$ Nouveaux dialogues des dieux, p. 37. - Há talvez aqui mais oposição de 
pontos de vista que contradição deliberada.

${ }^{278}$ Ed. 1767, p. 29.

${ }^{279}$ Pensées, ed. 1687, cap. XVIII, p. 144.

${ }^{280}$ Ed. 1687, cap. XXVIII, p. 271.

${ }^{281}$ Ed. 1767, p. 44. - Mesmo argumento na Analyse de la religion chrétienne. (Recueil nécessaire, p. 54).

${ }^{282}$ Examen des apologistes, 1667, cap. VIII, p. 119.

${ }^{283}$ Ed. 1687, cap. II, p. 26. - Ed. Brunschvicg, n 605.

${ }^{284}$ Cf. mais acima, p. 420.

285 p. $95-96$.

${ }^{286}$ p. 390.

${ }^{287}$ Discours sur les Pensées de M. Pascal, Lyon, 1688, p. 45.

${ }^{288}$ Ms. 2557.

${ }^{289}$ Levesque de Pouilly (Théorie des sentiments agréables) e Vauvenargues são a alinhar também entre os contraditores de Pascal, e Montesquieu assume também às vezes, parece, a ocasião de estabelecê-lo.

${ }^{290}$ p. 92-95.

${ }^{291}$ Histoire de la Régence, t. II, p. 252.

${ }^{292}$ p. 60.

293 Biographie Michaud, art. RAMSAY, t. XXXV, p. 158, n. 1, com referência à vida de Gensau nas Biographies de Busching, t. III, p. 314-338.

${ }^{294}$ Devo essa observação a Chérel, agregado de Letras, que prepara um trabalho sobre Ramsay. 